\title{
Middle Eocene large coccolithaceans: biostratigraphic implications and paleoclimatic clues
}

\author{
Carlotta Cappelli ${ }^{\mathrm{a}^{*}}$, Claudia Agnini ${ }^{\mathrm{a}, \mathrm{b}}$, Paul R. Bown ${ }^{\mathrm{c}}$, Martina De Riu ${ }^{\mathrm{a}}$ \\ ${ }^{a}$ Dipartimento di Geoscienze, Università di Padova, via Gradenigo 6-35131 Padova, Italy; e-mails: \\ carlotta.cappelli@unipd.it, claudia.agnini@unipd.it,martina.deriu@studenti.unipd.it \\ ${ }^{\mathrm{b}}$ Department of Geological Sciences, Stockholm University, SE-106 91 Stockholm, Sweden \\ ${ }^{\mathrm{c}}$ Department of Earth Sciences, University College London, London WC1E 6BT, United Kingdom; e-mail: \\ p.bown@ucl.ac.uk
}

\begin{abstract}
A combined light microscope-scanning electron microscope study of exceptionally wellpreserved calcareous nannofossil assemblages from clay-rich middle Eocene sediments recovered at IODP Site U1410 (NW Atlantic Ocean) has enabled us to document a new evolutionary lineage within Coccolithus-like placoliths that have well-developed near-axial or diagonal cross-bars in their central-area. Based on our observations, we describe a new genus Pletolithus, a new species Pletolithus giganteus and four new combinations (Pletolithus opdykei, Pletolithus staurion, Pletolithus mutatus and Pletolithus gigas). The distinctive ultra-structures of the different morphotypes and the presence of transitional morphologies suggest that Pletolithus evolved from a morphological variant of Coccolithus. The evolution of this group of coccolithaceans is initially characterized by increasing size and the appearance of delicate axial cross-bars in the central-area. Size continues to increase in these coccoliths and the orientation of the cross-bars shifts to asymmetric and diagonal in later representatives. Morphometric measurements on $P$. gigas and the morphologically similar $P$. giganteus, provide evidence for the presence of two distinct populations allowing for an objective differentiation of these two species, which in turn provides unambiguous taxonomic definition for the important biostratigraphic marker species $P$. gigas. These data improve the reliability of middle Eocene biostratigraphy and show that this lineage appeared when a new equilibrium in the environmental conditions was reached and intriguingly it coincides with a remarkable change in the deep circulation of the North Atlantic Ocean.
\end{abstract}

Key words: middle Eocene, calcareous nannofossils, Coccolithaceae, evolutionary lineage, centralarea cross-bars, Pletolithus.

\section{Introduction}

The Coccolithaceae is an extant coccolithophore family with a long geological record that extends back to the earliest Paleogene. This family represents a significant component of Paleogene assemblages, both in terms of abundances and species richness, and several representatives of this family are used as biostratigraphic markers in calcareous nannofossil biozonations (Martini, 1971; Okada and Bukry, 1980; Agnini et al., 2014).

Although the Cenozoic Family Coccolithaceae is a well-established taxonomic group (Young and Bown, 1997), the genus and species-level taxonomy of different coccolithaceans have been a matter of discussion for many authors (e.g., Gartner, 1970; Perch-Nielsen, 1985; Varol, 1992). One of the main taxonomic controversies concerns the generic classification of middle-Eocene Coccolithus-like coccoliths that possess robust crosses in the central-area (Bown and Newsam, 2017). A clear understanding of the evolution of these forms and an improved clarity of their taxonomy is of 
particular interest because their evolution preceded the appearance of the biozonal marker species Coccolithus gigas. The taxonomic definition of this biostratigraphically-significant species has become less clear in recent years, as a plexus of morphologically-related middle Eocene coccolithaceans has come to light, including transitional forms. This has led to uncertainties in the identification of $C$. gigas and undermined reliability of the stratigraphic placement of its origination and extinction levels, which are both widely applied in standard nannofossil zonations (e.g., CP13b total range zone of Okada and Bukry, 1980 and zones CNE10 and 11 of Agnini et al., 2014).

The time interval during which these morphotypes evolved, the middle Eocene, is a relatively little known and poorly studied interval, that lies between the extreme greenhouse conditions that peaked during the Early Eocene Climatic Optimum (EECO; c. 52-50 Ma) and the onset of Antarctic glaciation in the earliest Oligocene (e.g., Zachos et al., 2001, 2008). The global cooling trend that characterizes most of the middle Eocene, was accompanied by a remarkable decline in the species richness of calcareous nannofossils, suggesting a causal link between the climate deterioration and diversity loss (Aubry, 1992; 1998; Bown et al., 2004; Bown, 2005a). Calcareous nannoplankton are particularly important when trying to understand marine ecosystem dynamics because this group was the main primary producer of the Paleogene lying at the base of the ocean food chain and plays a fundamental role in the organic (biomass) and inorganic $\left(\mathrm{CaCO}_{3}\right.$ test) carbon cycle. Their abundance, wide biogeographic distribution and rapid evolutionary rates make them the perfect tool with which to investigate short-and long-term modifications of plankton communities and particularly the influence of climate-ocean system change through time.

The early to middle Eocene time interval is well represented at Integrated Ocean Drilling Program (IODP) Site U1410 (northwest Atlantic Ocean, Norris et al., 2014) and the section shows a major change in sedimentary regime related to the onset of drift sedimentation (Norris et al., 2014; Bornemann et al., 2016; Boyle et al., 2017; Coxall et al., 2018). At this site, the middle Eocene deposits occur as expanded packages of clay-rich sediments that contain nannofossils with an exquisite quality of preservation (Norris et al., 2014; Plates 1-6, herein).

Here we document the evolution of the Coccolithus gigas group using the exceptionally wellpreserved nannofossil assemblages from Site U1410. Our reassessment of these large middle Eocene coccolithaceans aims to provide a more rigorous and practical taxonomy for this group, and, in turn, to improve the use of $C$. gigas in the current biozonation schemes. In addition, we compare the paleontological record with paleoenvironmental conditions at the early-middle Eocene transition in the Northwest Atlantic, shedding new light on the abiotic background that might have favored the radiation of these distinctive forms.

\section{Materials and methods}




\subsection{Geological Setting}

IODP Site U1410 is located in the Northwest Atlantic on the Southeast Newfoundland Ridge (Latitude: $41^{\circ} 19.6987 \mathrm{~N}$; Longitude: $49^{\circ} 10.1995$ W) (Fig. 1). During the Eocene, sediments were deposited at an estimated paleo-water depth of $2950 \mathrm{~m}$, well above the calcite compensation depth (CCD) for this time interval. The lower Eocene sediments are pinkish-white nannofossil chalk (Unit IV, Norris et al., 2014) overlain by middle Eocene greenish-gray nannofossil ooze with some bands $(10-25 \mathrm{~cm})$ of light gray to white nannofossil ooze (Unit III, Norris et al., 2014). The middle Eocene succession is characterized by high accumulation rates (c. $2.2 \mathrm{~cm} / \mathrm{k} . \mathrm{y}$.) reflecting clay-rich drift deposition, and contains exceptionally well preserved calcareous nannofossils (Norris et al., 2014; Bown and Newsam, 2017).

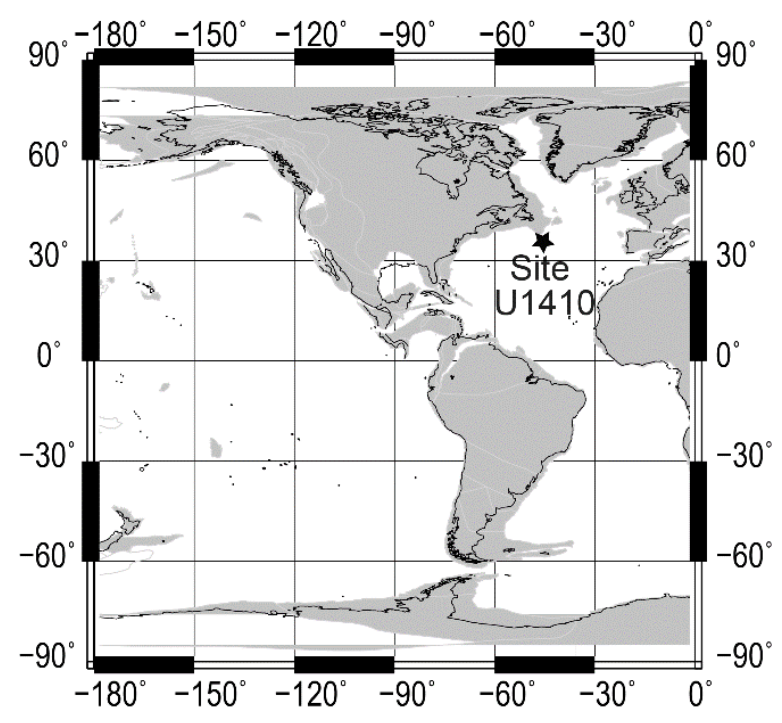

Figure 1: Paleo-geographic map of the middle Eocene (45 Ma) showing the location of IODP Site U1410 (www.odsn.de).

The samples used in this study were selected based on the shipboard splice (Norris et al., 2014), which has been modified by Boulila et al. (2018) and later by Cappelli et al. (submitted). As a consequence, samples used in this study were not originally incorporated in the latest version of the splice, but their depths have been recalculated using the new corrected revised meter composite depth (crmcd) scheme. Magnetostratigraphic data are from Yamamoto et al. (2018), but positions of chron boundaries have been converted to the new splice (Cappelli et al., submitted). The study interval ranges from Zone CP10 to Subzone CP13c of Okada and Bukry (1980) or from Zone CNE4 to Zone CNE12 of Agnini et al. (2014), based on the presence of Discoaster lodoensis at the base of the 
section, and the absence of Pletolithus gigas (see taxonomic notes) and rare Reticulofenestra umbilicus in the upper part of the section (Cappelli et al., submitted).

\subsection{Light microscope samples preparation and observation techniques}

The composite section for Site U1410, modified after Cappelli et al., (submitted), was studied from 303.29 to $147.40 \mathrm{crmcd}$. Samples were prepared as smear slides with standard methods (Bown and Young, 1998) and analyzed using transmitted-light microscopy (x1250 magnification). The counting of the Coccolithus gigas group morphotypes was performed on in a pre-fixed area of 1 or $2 \mathrm{~mm}^{2}$ (normalized to $1 \mathrm{~mm}^{2}$ ). During the light microscope (LM) quantitative study we did not differentiate Pletolithus opdykei from Pletolithus staurion (see taxonomic notes), and therefore refer to them here as the Pletolithus staurion group.

The biostratigraphic analysis and stable isotope data from bulk sediments are described in more detail in Cappelli et al. (submitted). The biostratigraphic schemes applied are the standard biozonations of Martini (1971) and Okada and Bukry (1980), together with the more recent Agnini et al. (2014) scheme. Following Agnini et al. (2014), biostratigraphic events are termed Base (B), Top (T), Base Continuous and Common (Bc), and Top Continuous and Common (Tc) to describe stratigraphically lowest, highest and lowest continuous/common occurrences, respectively. Calcareous nannofossils were identified to species level following the taxonomic concepts of various authors (e.g., PerchNielsen, 1985; Bown, 2005b; Bown and Dunkley Jones, 2006, 2012; Agnini et al., 2014; Bown and Newsam, 2017) but detailed taxonomic descriptions of forms belonging to the Coccolithus gigas group (Bown and Newsam, 2017) are provided herein to enable unambiguous taxonomic definitions. Morphometric measurements of specimens belonging to the species $C$. gigas and morphologically similar forms, were performed on a total of 23 samples. Well-preserved specimens (80) were imaged using an Invenio 5D II digital camera and measured using DeltaPix InSight software. Different biometric parameters were determined for each specimen, including size (placolith length, placolith width and placolith area), geometry of the central-area (central opening length, central opening width and central opening area), and length of the central-area cross-bars. Morphometric data were then plotted using PAST software (Hammer et al., 2001).

\subsection{Sample preparation and observation techniques for scanning electron microscope analysis}

Selected samples were studied by scanning electron microscopy (SEM) using a JEOL Digital JSM6480LV SEM at University College London (UCL). In order to observe the same individual specimens in both LM and SEM, several samples were prepared following the technique proposed by Gallagher (1988). This was achieved by first printing a grid (Fig. 2) onto round cover slips (12 
mm diameter) using a LED UV printer and a UV ink. A few drops of dilute sample solution were placed onto the cover slip and allowed to dry on a hot plate. For the LM analysis, the cover slip with sediment was placed on a rectangular microscope slide $75 \times 25 \mathrm{~mm}$ and a few drops of distilled water added to allow penetration of transmitted light. Distilled water was used instead of methanol, as originally suggested by Gallagher (1988), because the use of the latter is now discouraged for safety reasons. Finally, we covered the circular cover slip with a rectangular cover slip $(24 \times 24 \mathrm{~mm})$, and fixed it using tape or blu-tack. In LM, the positions of selected specimens were recorded with reference to the grid notation. Images of the grid at different magnifications were taken and used to re-locate the exact position of the study specimen. After LM analysis, the rectangular cover slip is carefully removed and the circular cover slip dried at low temperature on a hot plate. For SEM study, the circular cover slip is mounted on an SEM Stub using a carbon adhesive and coated with a layer of gold. In SEM, the ink of the grid is still visible and the specimen identified in LM can be re-located and imaged. It is worth noting that this technique did not work perfectly because of occasional movement of nannofossils during removal of the cover slip and/or during the drying phase. However, the benefit was the unequivocal viewing of the same specimens in both LM and SEM, providing high quality morphological information.

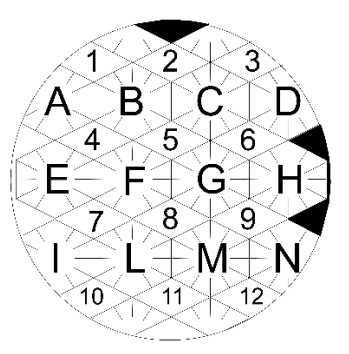

Figure 2: Example of grid printed in ink on a $12 \mathrm{~mm}$ diameter cover slip.

\section{Taxonomic background}

The Family Coccolithaceae is characterized by the possession of Coccolithus-type placolith rim structure as described by Young (1992). These placoliths have V-units forming both the distal shield and proximal layer of the inner tube cycle, and R-units that form a bicyclic proximal shield and the distal layer of the inner tube (Young, 1992). Classification among Coccolithaceae at the genus level is based on three morphologic features: i) the tube-cycle width, ii) the central-area width and iii) the structures occupying the central-area. The main genera - Coccolithus, Chiasmolithus, Cruciplacolithus, Campylosphaera, Clausicoccus, Bramletteius and Ericsonia - are shown in Figure 3. 


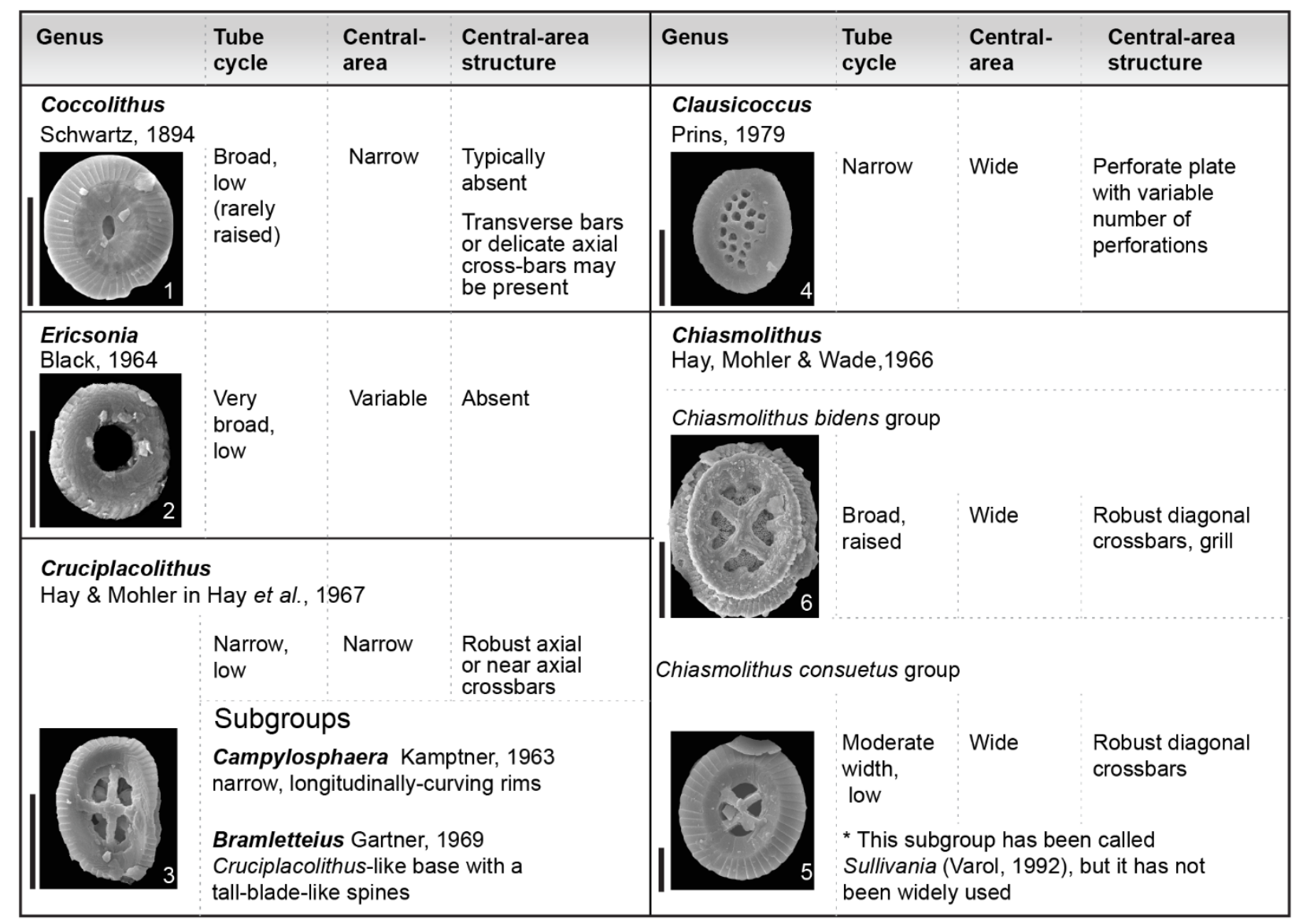

Figure 3: Schematic figure summarizing the distinctive features of selected genera belonging to Family Coccolithaceae. SEM images of representatives of the genera are also provided. 1. Coccolithus pelagicus, Sample U1410B-21X-3, 127. 2. Ericsonia subpertusa from Bown (2016). 3. Campylosphaera dela, Sample U1410B-21X-CC. 4. Clausicoccus fenestratus, Sample U1410C-19X-2, 67. 5. Chiasmolithus consuetus, Sample U1410B-21X-3W, 127. 6. Chiasmolithus grandis, Sample U1410C-19X-2, 67. All scale bars represent $5 \mu \mathrm{m}$.

During the middle Eocene, Coccolithus-like coccoliths with broad tube cycles, narrow central-areas and well-developed axial or non-axial cross-bars are widely reported (e.g., Perch-Nielsen, 1985). These taxa, C. gigas, C. staurion, C. opdykei, C. mutatus, have been recently included in an informal Coccolithus gigas group (Bown and Newsam, 2017) but have previously been assigned to a variety of genera including Chiasmolithus, Cruciplacolithus or Coccolithus, mainly based on central-area features rather than considerations of overall morphology and phylogenetic relationships. The main species included within the $C$. gigas group are described in the taxonomic notes section, but note that we propose a new genus, Pletolithus, to formalize the grouping of these taxa.

An additional taxon of interest for our discussion is Coccolithus pelagicus. This species first appeared in the early Danian and is still present in the modern oceans (Perch-Nielsen, 1985). Most of the fossil coccoliths of $C$. pelagicus lack any central-area structure although some forms throughout its stratigraphic range possess fragile cross-bars that are typically not visible in LM (e.g., Bown, 2010). Fossil Coccolithus-like coccoliths (i.e., with broad rims, broad tube cycles and narrow central-area) when seen with narrow cross-bars have often been classified within 
Cruciplacolithus (e.g., C. tenuiforatus Clocchiatti and Jerkovic, 1970) even if they occur well outside the typical range of the Cruciplacolithus genus, which is typically Paleocene. The wide range of sizes of fossil $C$. pelagicus and morphological variations seen in the modern species (Sáez et al., 2003) likely indicates the presence of cryptic species but detailed morphological and morphometric analysis is required to understand this group more fully (Bown, 2010).

\section{Results}

\subsection{Light microscope observations and morphometric results}

Calcareous nannofossils are abundant throughout the study interval and their preservation ranges from good to excellent. The extraordinary quality of preservation observed in the middle Eocene study interval is explained by the clay-rich nature of the sediments, with the clay acting as a protection that prevents recrystallization and overgrowth (Bown and Newsam, 2017).

At Site U1410, Pletolithus mutatus (see taxonomic notes) is observed from Zone CNE8 to the top of the section and is rare but nearly continuously present throughout this interval (Fig. 4).

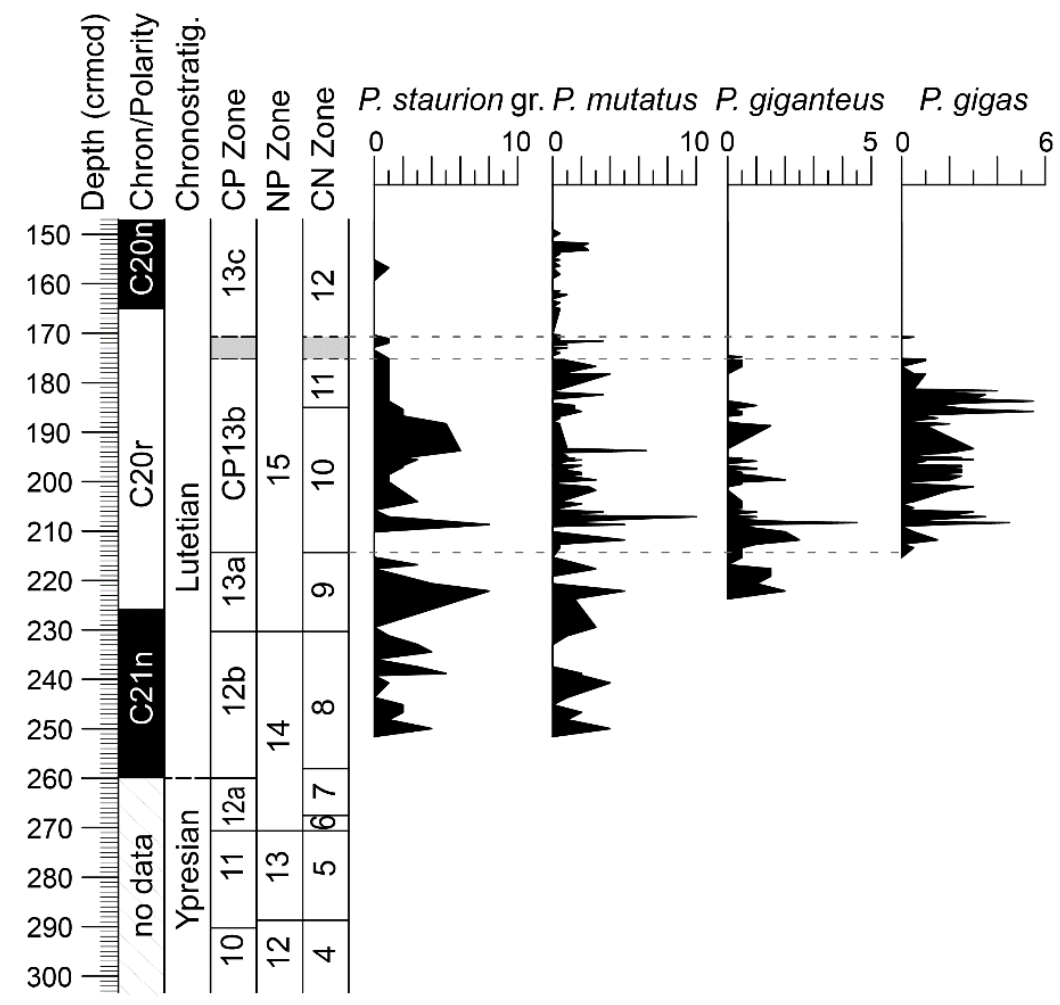

Figure 4: Abundance pattern $\left(\mathrm{n} / \mathrm{mm}^{2}\right)$ of species belonging to the studied Coccolithaceae lineage. Depth (crmcd), magnetostratigraphy and calcareous nannofossil biostratigraphy (Cappelli et al., submitted); CP Zone (Okada and Bukry, 1980), NP Zone (Martini, 1970) and CN Zone (Agnini et al., 2014), are shown on the left.

P. mutatus is very distinctive under LM, especially the thick tube-cycle margin which appears as a narrow orange ring in XPL (Fig. 5, figs F-J). The Pletolithus staurion group appears in the record at 
the same level as P. mutatus (Fig. 4, Fig. 5, figs. A-E). Pletolithus giganteus sp. nov. (see taxonomic notes, Fig. 6, figs A-F) first appears in the upper part of Zone CNE9 (Fig. 4), predating the first entry of P. gigas by $8.57 \mathrm{~m}$ (c.320 kyr). Pletolithus gigas (Fig. 6, figs G-J) is generally rare with a sharp decline in abundance towards the top of its stratigraphic range, which is coincident with Base common Sphenolithus cuniculus (Zone CNE11, Fig. 4). Pletolithus giganteus displays a decline in abundance before its extinction, which predates the extinction level of $P$. gigas by c. $8 \mathrm{~m}$ (c. $300 \mathrm{kyr})$. 

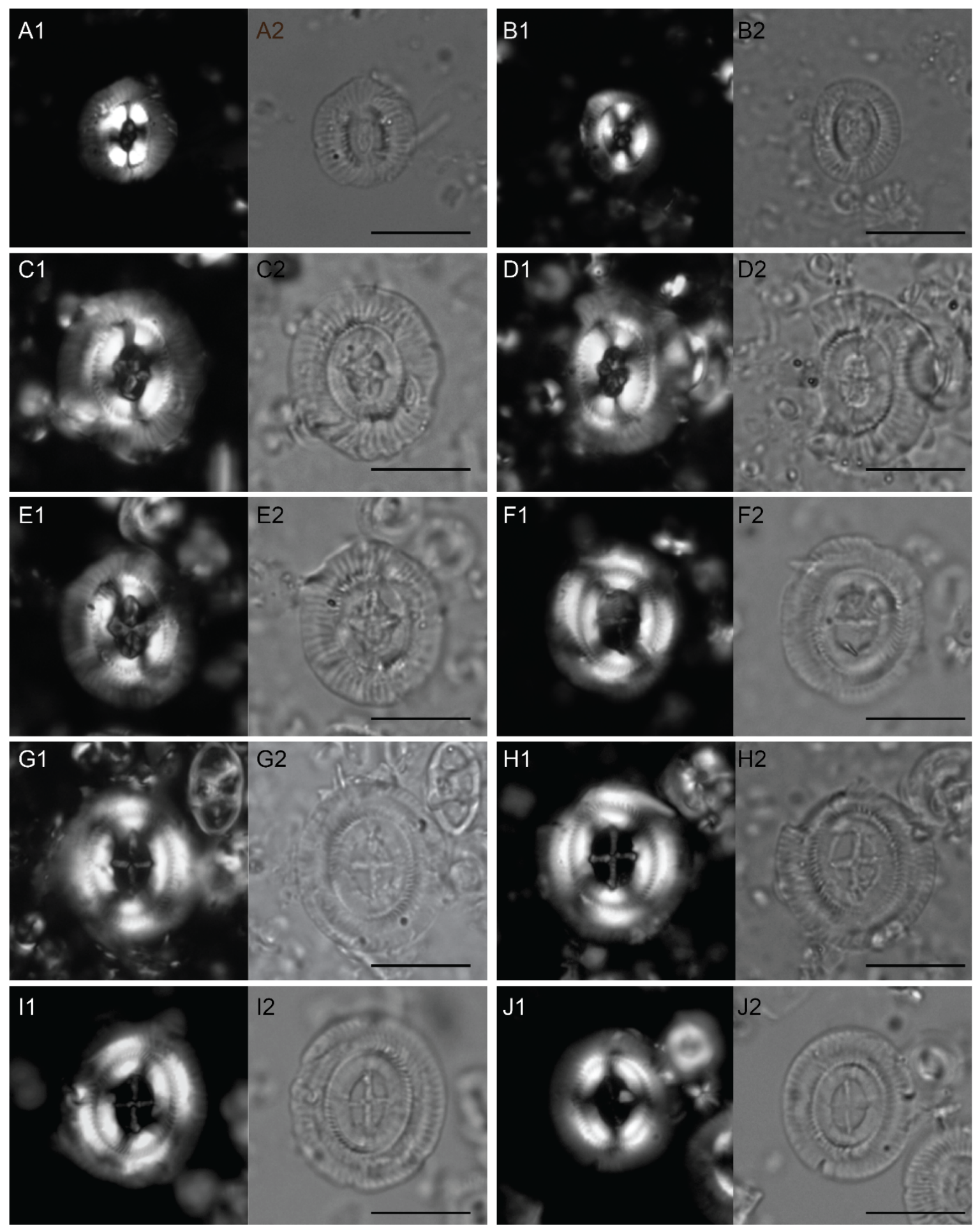

Figure 5: LM images of Pletolithus from IODP Site U1410. Scale bar $10 \mu \mathrm{m}$ A. Pletolithus opdykei, Sample U1410B20X-5, 40. 1. Crossed nicols, 2. Parallel nicols. B. Pletolithus opdykei, Sample U1410B-21X-3, 127. 1. Crossed nicols, 2. Parallel nicols. C. Pletolithus staurion, Sample U1410B 21X-3, 127. 1. Crossed nicols, 2. Parallel nicols. D. Pletolithus staurion, Sample U1410C-20X-6, 67. 1. Crossed nicols, 2. Parallel nicols. E. Pletolithus staurion, Sample U1410C-20X4, 67. 1. Crossed nicols, 2. Parallel nicols. F. Pletolithus mutatus, Sample U1410B-23X-2, 7. 1. Crossed nicols, 2. Parallel nicols. G. Pletolithus mutatus, Sample U1410C-20X-5, 67, 1. Crossed nicols, 2. Parallel nicols. H. Pletolithus mutatus, U1410B 21X-4, 127. 1. Crossed nicols, 2. Parallel nicols. I. Pletolithus mutatus, Sample U1410C-18X-5, 20. 1. Crossed nicols, 2. Parallel nicols. J. Pletolithus mutatus, Sample U1410C-18X-5, 20. 1. Crossed nicols, 2. Parallel nicols. 

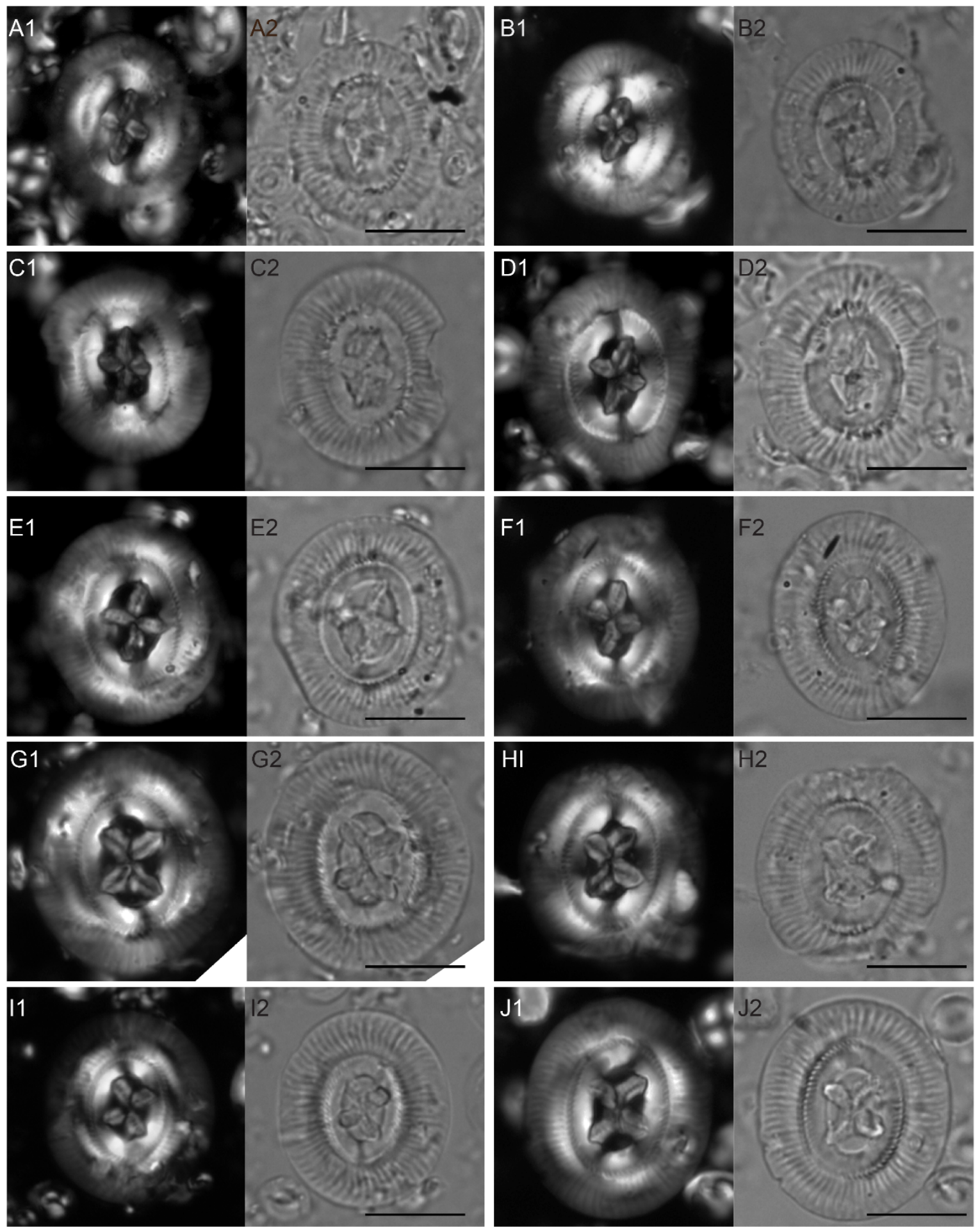

Figure 6: LM images of Pletolithus from IODP Site U1410. Scale bar $10 \mu \mathrm{m}$. A. Pletolithus giganteus (paratype), Sample U1410C-20X-6, 67. 1. Crossed nicols, 2. Parallel nicols. B. Pletolithus giganteus, Sample U1410C-20X-6, 67. 1. Crossed nicols, 2. Parallel nicols. C. Pletolithus giganteus, Sample U1410C 20X-4, 67. 1. Crossed nicols, 2. Parallel nicols. D. Pletolithus giganteus (holotype), Sample U1410C-20X-3, 67. 1. Crossed nicols, 2. Parallel nicols. E. Pletolithus giganteus, Sample U1410C-20X-3, 67. 1. Crossed nicols, 2. Parallel nicols. F. Pletolithus giganteus, Sample U1410B20X-5, 40 1. Crossed nicols, 2. Parallel nicols. G. Pletolithus gigas, Sample U1410C-19X-2, 67. 1. Crossed nicols, 2. Parallel nicols. H. Pletolithus gigas, Sample U1410B 20X-5, 40 1. Crossed nicols, 2. Parallel nicols. I. Pletolithus gigas, Sample U1410C-18X-3, 60. 1. Crossed nicols, 2. Parallel nicols. J. Pletolithus gigas, Sample U1410C-18X-4, 80. 1. Crossed nicols, 2. Parallel nicols. 
The other large coccolithaceans, the $P$. staurion group and $P$. mutatus, range significantly above $P$. gigas, although they become extremely rare and sporadic. We also observed specimens with morphology intermediate between $P$. gigas and $P$. giganteus, i.e., with cross-bars intermediately oriented, and in order to develop a taxonomic definition that is objective and easy to apply, we analyzed 23 samples containing these forms. These morphometric analyses are presented as scatter plots (Fig. 7A), which reveal a wide spread of values for most of the morphometric parameters, except for the bar-length ratio, i.e., the ratio between the length of the long and short cross-bars. This is best illustrated by the frequency histograms (Fig. 7B), which show that the bar-length ratio displays a clear bimodal distribution pattern, with 1.3 representing the ratio value that separates two distinct populations. If other morphological features are also considered, for example, the orientation of the cross-bars, it becomes apparent that the population with smaller bar-length ratios (average $=1.16$ ) coincides with the $P$. gigas species concept, with diagonal cross-bars. The forms with bar-length ratios $>1.3$ (mean value $=1.38$ ) are equivalent to the informal Coccolithus $\mathrm{cf}$. gigas concept, with asymmetric cross-bars, providing support for the differentiation of a separate taxon, which we formally describe here as $P$. giganteus. Although, there is overlap between the placolith surface area values of the two taxa, $P$. gigas have higher values, and the average values are significantly different, specifically 294.51 and 251.62 , respectively. 
A
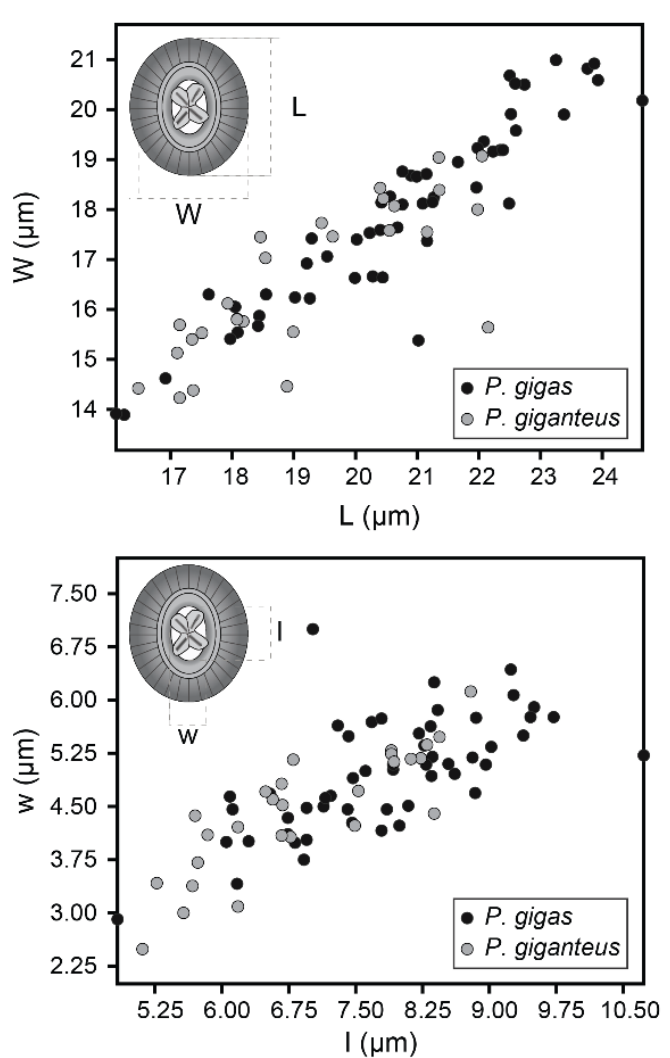

B
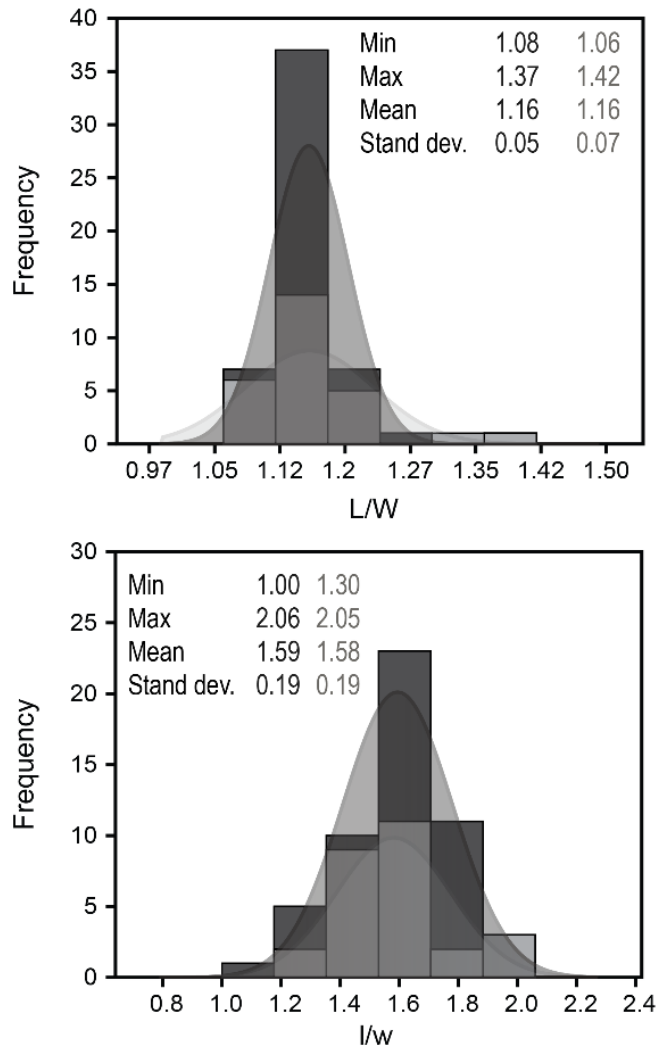
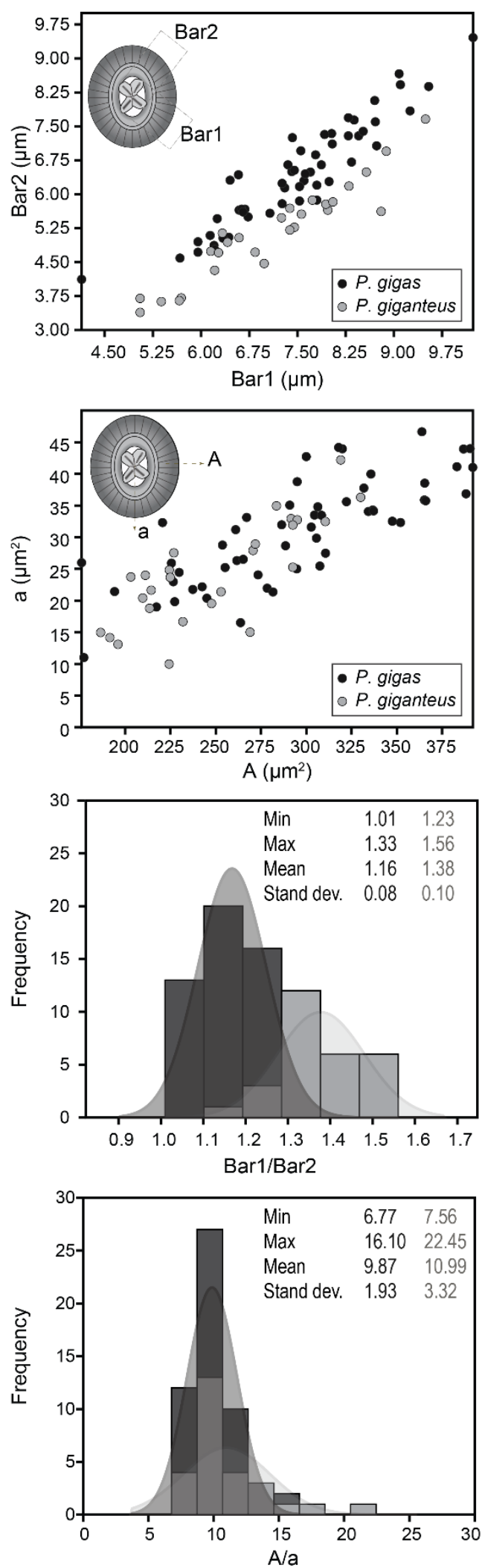

Figure 7: Plots comparing the measured morphological parameters. A) Scatter plots of placolith length (L) versus placolith width (W), long bar length (Bar 1) versus short bar length (Bar 2), central-area length (1) versus central-area width (w), area placolith (A) versus central-area (a). B) Frequency histograms of morphological parameters L/W, Bar1/Bar2, 1/w and A/a. 


\subsection{SEM observations}

The exquisite preservation of the middle Eocene nannofossils indicated by LM observations is fully confirmed also by the SEM analysis, which reveals the presence of small and fragile structures, such as delicate central-area cross-bars in a significant number of small and medium sized C. pelagicus morphotypes (Fig. 8, figs B-F) and submicron-scale nets in other members of the Coccolithaceae, e.g., Chiasmolithus.

Our SEM observations of $P$. mutatus show that it possesses typical Coccolithus-like rim structure with a very distinctive, broad, raised, distal tube-cycle (Fig. 9, figs B, C, E) and central-area crossbars consisting of one set of staggered plates arranged in a single row, both on the distal and proximal sides (Fig. 9, figs B-E). These cross-bars are comparable with those of Paleogene C. pelagicus (i.e., C. tenuiforatus of some authors) (Fig. 8, figs B-E) and the fact that they are more conspicuous in LM is likely due to the larger size of the coccolith overall. The cross-bars are very delicate and despite the exceptional preservation, specimens with broken or missing cross-bars were observed (Fig. 9, fig. E). SEM images show that the cross-bars of P. staurion and P. opdykei (Fig. 8, figs G, H; Fig. 9, fig. A) are similar in structure, but broader and more robust than those of $P$. mutatus. On the proximal side, these bars consist of one row of robust plates, whose axis is transversely oriented with respect to the bar axes (Fig. 8, figs G2, H2; Fig. 9, fig. A2).

In SEM, P. giganteus and P. gigas (Fig. 10) show a wide and low tube-cycle with broad, robust crossbars. On the proximal side, the bars consist of interfingering wedge-shaped elements that are transversely oriented with respect to the long axis of each bar (Fig. 10, figs C2, F2). On the distal side, overlapping rectangular plates are nearly aligned with the bar axis (Fig. 10, figs A2, B2). This arrangement of cross-bar elements gives rise to a conspicuous axial extinction line along the bar axes in XPL (Fig. 6).

Our SEM study reveals that specimens included within Chiasmolithus (Fig. 11) have significantly different cross-bar ultrastructure, compared with the Pletolithus group (see also Gartner, 1970). Chiasmolithus consuetus is characterized by simpler bar ultrastructure than Pletolithus, with overlapping tabular calcite plates stacked one on the other and closely appressed on both the distal and proximal sides (Fig. 12, figs A-F). In contrast, species belonging to Chiasmolithus grandis, Chiasmolithus expansus, and Chiasmolithus solitus have relatively complex bar construction, but differ from Pletolithus because on the proximal side they consist of two rows of transversely aligned laths and by a third row of small elements arranged along the bar axes (Fig. 12, figs J, K, M). 


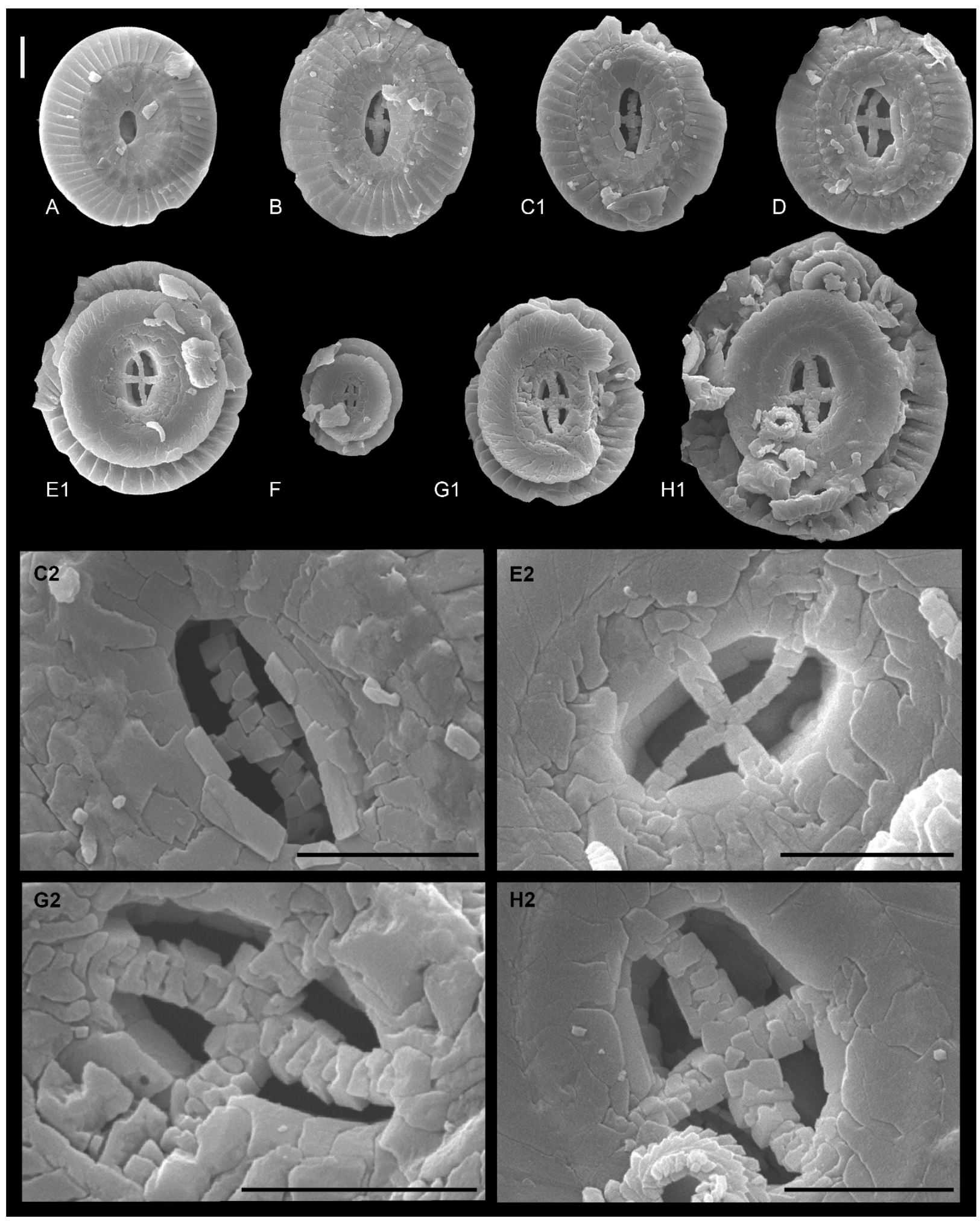

Figure 8: SEM images from IODP Site U1410. All scale bars represent $2 \mu \mathrm{m}$. A. Coccolithus pelagicus, distal view, Sample U1410A-18X-CC B. Coccolithus pelagicus with gracile cross-bars in the central-area in distal view, Sample U1410B-21X-3, 127. C. Coccolithus pelagicus with gracile cross-bars in the central-area in distal view, Sample U1410B21X-3, 127. C1. Complete placolith in distal view, C2. Detail of central-area cross-bars. D. Coccolithus pelagicus with gracile cross-bars in the central-area, Sample U1410C-20X-4, 67. E. Coccolithus pelagicus with gracile cross-bars in the central-area, Sample U1410C-19X-2, 67. E1. Complete placolith in proximal view E2. Detail of central-area cross-bars. F. Very small Coccolithus pelagicus with gracile cross-bars in the central-area, Sample U1410B-21X-CC. G. Pletolithus opdykei in proximal view, Sample U1410B-21X-3, 127. G1. Complete placolith in proximal view, G2. Detail of centralarea cross-bars. H. Pletolithus staurion, Sample U1410B-21X-3, 127. H1. Complete placolith in proximal view, H2. Detail of central-area cross-bars. 


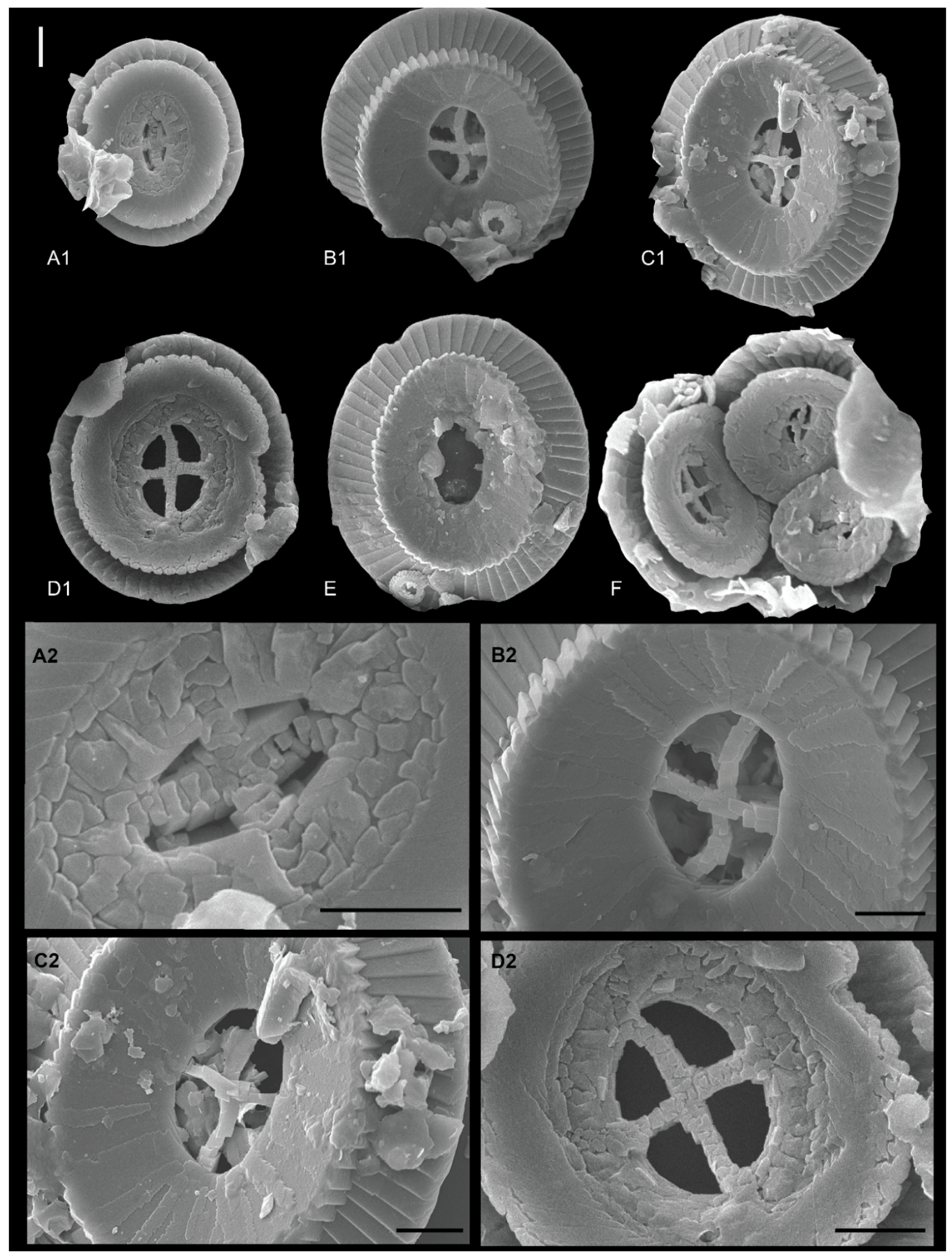

Figure 9: SEM images from IODP Site U1410. All scale bars represent $2 \mu \mathrm{m}$. A. Pletolithus opdykei, Sample U1410B 21X-3, 127. A1. Complete placolith in proximal view, A2. Detail of central-area cross-bars. B. Pletolithus mutatus, Sample U1410C 19X-2, 67. B1. Complete placolith in distal view, B2. Detail of central-area cross-bars. C. Pletolithus mutatus, Sample U1410B-21X-3, 127. C1. Complete placolith in distal view, C2. Detail of central-area cross-bars. D. Pletolithus mutatus, Sample U1410B-23X-4, 7. D1. Complete placolith in proximal view, D2. Detail of central-area crossbars. E. Pletolithus mutatus (distal view) with broken cross-bars, Sample U1410B-21X-3, 127. F. Coccolithus pelagicus coccosphere with fragile cross-bars in the central-area, coccosphere, Sample U1410C-19X-2, 67. 


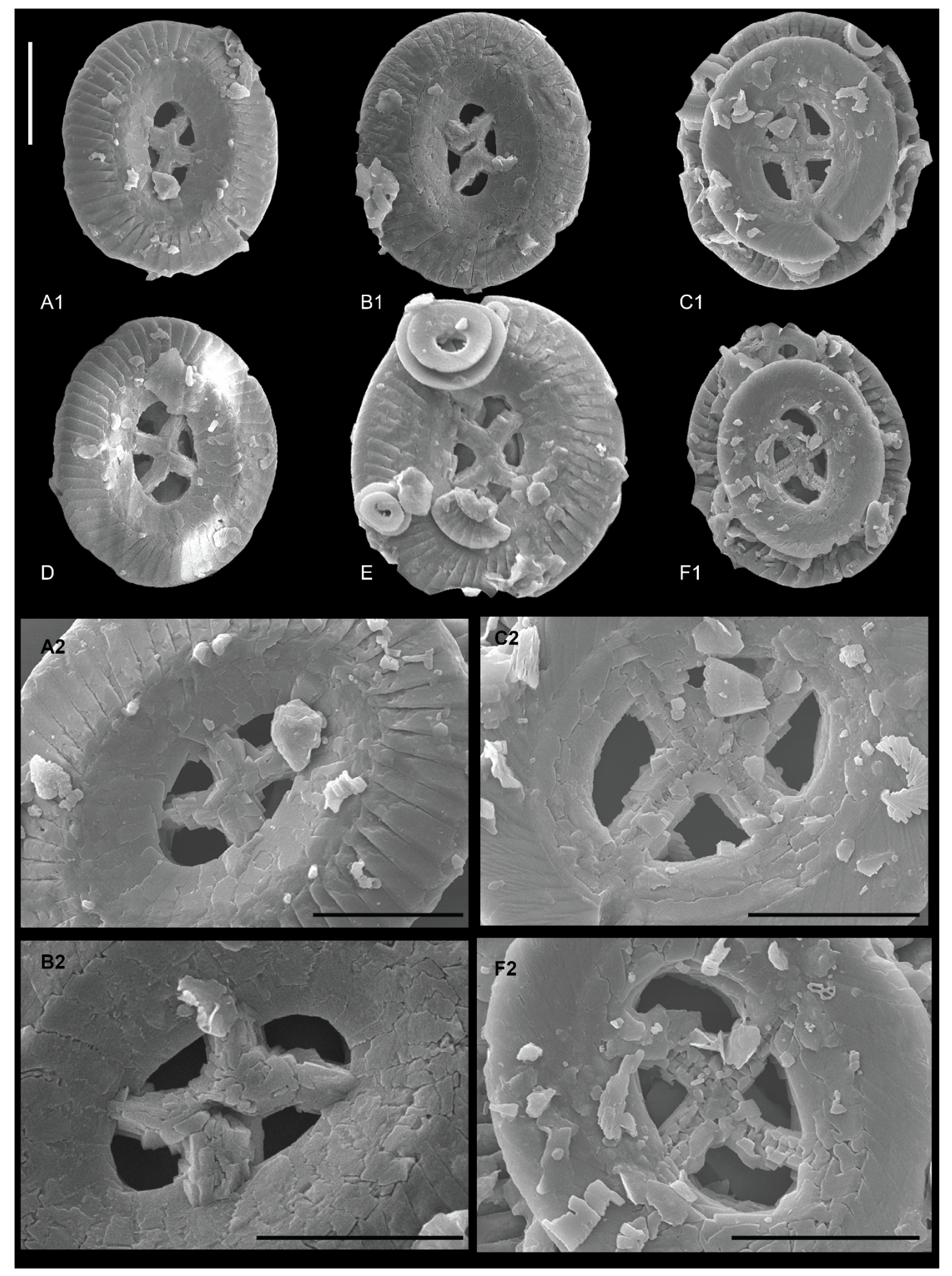

Figure 10: SEM images from IODP Site U1410. All scale bars represent $5 \mu \mathrm{m}$. A. Pletolithus giganteus, Sample U1410B21X-3, 127. A1. Complete placolith in distal view, A2. Detail of central-area cross-bars. B. Pletolithus giganteus, Sample U1410C-19X-3, 65. B1. Complete placolith in distal view, B2. Detail of central-area cross-bars. C. Pletolithus giganteus, Sample U1410B-21X-3, 127. C1. Complete placolith in proximal view, C2. Detail of central-area cross-bars. D. Pletolithus gigas, Sample U1410C-19X-2, 67. E. Pletolithus gigas, Sample U1410C-18X-CC. F. Pletolithus gigas, Sample U1410B-21X-3, 127. F1. Complete placolith in proximal view, F2. Detail of central-area cross-bars. 


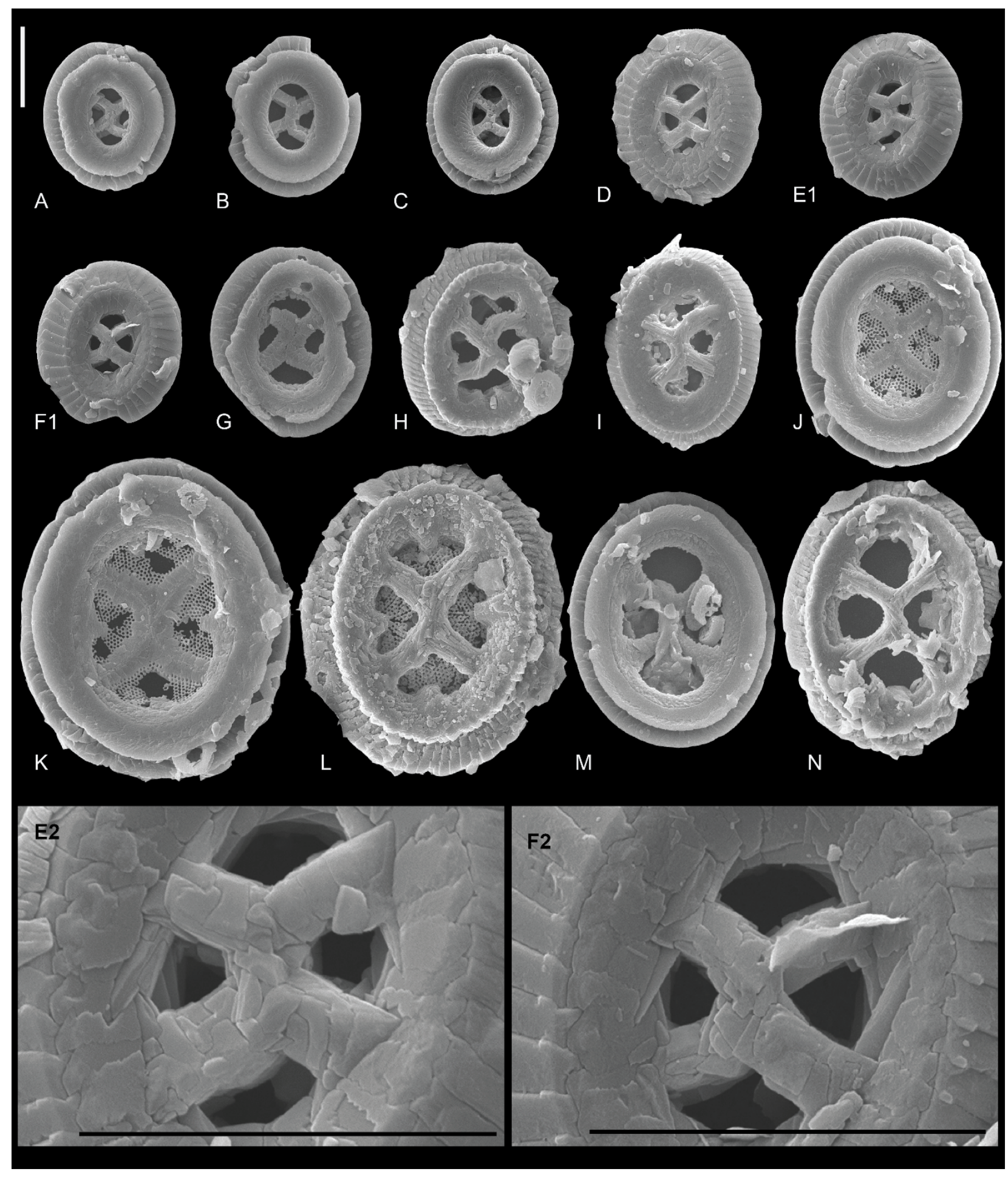

Figure 11: SEM images from IODP Site U1410. All scale bars represent $5 \mu \mathrm{m}$. A. Chiasmolithus consuetus (proximal view), Sample U1410B-21X-3, 127. B. Chiasmolithus consuetus (proximal view), Sample U1410B-21X-3, 127. C. Chiasmolithus consuetus (proximal view), Sample U1410B-21X-3, 127. D. Chiasmolithus consuetus (distal view), Sample U1410C-19X-2, 67. E. Chiasmolithus consuetus, Sample U1410B-21X-3, 127. E1. Complete placolith in distal view, E2. Detail of central-area cross-bars. F. Chiasmolithus consuetus, Sample U1410B-21X-3, 127. F1. Complete placolith in proximal view, F2. Detail of central-area cross-bars. G. Chiasmolithus solitus (proximal view), Sample U1410B-21X-3, 127. H. Chiasmolithus solitus (distal view), Sample U1410B-21X-3, 127. I. Chiasmolithus solitus (distal view), Sample U1410A-17X-2, 120 J. Chiasmolithus solitus (proximal view), Sample U1410B-21X-3, 127. K. Chiasmolithus grandis (proximal view), Sample U1410B-21X-3, 127. L. Chiasmolithus grandis (distal view), Sample U1410C-19X-2, 67. M. Chiasmolithus expansus (proximal view), Sample U1410A-21X-3, 127. N. Chiasmolithus expansus (distal view), Sample U1410A-21X-3, 127. 


\section{Discussion}

\subsection{Biometric parameters and the differentiation of Pletolithus gigas}

The $P$. giganteus and $P$. gigas morphometric data indicates a continuous morphological gradient between the two taxa with forms showing progressive rotation of the central-area cross-bars from near-axial to near-diagonal prior to the establishment of the separate $P$. gigas species. This gradual transition makes differentiation of these taxa difficult, especially using subjective visual assessment. To minimize this subjectivity, Bown and Newsam (2017) proposed that the angle formed between the long axis of the placolith and the central structure should be used as the main criterion to distinguish $P$. giganteus from $P$. gigas. However, this parameter is difficult to measure especially if preservation is not optimal because recrystallization can obscure the central structures and, more importantly, the precise identification of the long axis in these large placoliths is challenging. Instead we propose the use of bar-length ratio, with the threshold value of 1.3 applied to differentiate the species, with $P$. gigas $<1.3$ and $P$. giganteus $>1.3$. This parameter is easy to apply and displays a direct correlation with the parameter previously suggested by Bown and Newsam (2017): the larger the bar-length ratio, the smaller the angle between the central structure and the long axis of the placolith.

\subsection{Evolutionary trends}

Calcareous nannofossil evolutionary lineages and the possible relationships between different taxa are largely based on morphological criteria and stratigraphic data, because molecular data are not available for these fossils and mostly extinct forms. The unusual morphology of $P$. gigas and the presence of robust cross-bars in the central-area have led to a variety of different suggestions on its origins, e.g., Chiasmolithus solitus (Romein, 1979), Chiasmolithus californicus (Perch-Nielsen, 1985) and Sullivania minima (Varol, 1992) have all been proposed as possible ancestoral species.

Our results indicate that $P$. gigas evolved from $P$. giganteus (C. cf. gigas of Bown and Newsam, 2017). Our morphological and morphometric analyses highlight that ancestral P. giganteus forms with axial or near-axial cross-bars gave rise to transitional forms with near-diagonal bars, then to $P$. gigas with diagonal bars, supporting a phylogenetic relationship between these two taxa that is confirmed by overlapping stratigraphic ranges. Once the $P$. gigas morphology is established, the bimodal distribution of bar-length ratios indicates the continued presence of two distinct morphotypes, which are relatively easy to distinguish. Pletolithus gigas also has a discrete stratigraphic range, which is shorter than that of $P$. giganteus. These features are indicative of a cladogenetic evolutionary model, where $P$. gigas and $P$. giganteus represent two separate species. As 
to the ancestral form of $P$. giganteus, a likely candidate is $P$. staurion according to Bown and Newsam (2017).

The identification of the P. staurion group - P. giganteus - P. gigas lineage, where early forms have axial or near-axial cross-bars, broad, flat, distal tube-cycles and relatively narrow central-areas is strongly suggestive of divergence from a Coccolithus ancestor rather than Chiasmolithus. This is further supported by the distinct ultrastructure of the central-area cross-bars in P. giganteus and $P$. gigas, compared to those of Chiasmolithus. We include within this lineage the species P. mutatus, $P$. opdykei, $P$. staurion, $P$. giganteus and $P$. gigas with the ancestral form likely a variant of Coccolithus pelagicus bearing gracile axial cross-bars. The virtually coincident first appearances of the $P$. staurion group and P. mutatus in the lower-middle part of Chron C21n (c. $47 \mathrm{Ma})$ marks the onset of an increase in size of the placoliths within this group and of the central-area cross-bars. Among calcareous nannofossils, the repeated evolution of similar morphological features has been observed in many groups at different stratigraphic levels, especially the recurrent appearance of cross-bars that change orientation from axial to diagonal. Similar morphological trends are seen in the Cretaceous Eiffellithus lineage (Watkins and Bergen, 2003; Shamrock and Watkins, 2009) and in the early Paleocene Cruciplacolithus-Chiasmolithus lineage (Romein, 1979; Van Heck and Prins, 1987).

\subsection{The new genus Pletolithus}

The generic classification of $P$. gigas and related forms has remained contentious and at present different genera are used for a number of these species, e.g., Coccolithus, Cruciplacolithus or Chiasmolithus. As the presence and orientation of cross-bars has been used as a higher taxonomic level criterion (e.g., genus), this may result in generic groups being polyphyletic, grouping superficially similar morphologies which are nevertheless not closely related because of the iterative evolution of common central-area structures, such as, diagonal cross-bars. This is the case for $P$. gigas, which has usually been ascribed to Chiasmolithus based on its diagonally-orientated crossbars, but as we have shown here, this species is more closely related to the genus Coccolithus having evolved from ancestral forms with gracile axial cross-bars. Similarly, P. mutatus and P. staurion have previously been considered part of the genus Cruciplacolithus based on the presence of axial crossbars, but their rim morphology and stratigraphic distribution suggests they are phylogenetically distinct from Paleocene Cruciplacolithus and are likely more closely allied to Coccolithus.

Our interpretation of this middle Eocene group of large coccolithaceans raises questions concerning the generic classification of these forms. It is now clear that this group is closely affiliated with Coccolithus, and the use of Chiasmolithus or Cruciplacolithus for species within it will result in polyphyletic taxa. Here we propose a new genus, Pletolithus (see taxonomic note) to encompass this 
stratigraphically and morphologically distinct group of Coccolithus-like forms, which share large size and relatively robust central-area cross-bars with varying orientation.

\subsection{Large middle Eocene coccolithaceans and their use in biostratigraphy}

Pletolithus gigas is a well-established zonal marker species in middle Eocene calcareous nannofossil biostratigraphy. The Base and the Top of $P$. gigas are the primary marker events defining the base of nannofossil subzones CP13b and CP13c of Okada and Bukry (1980) and the base of zones CNE10 and CNE12 of Agnini et al. (2014). Pletolithus gigas possesses some of the attributes of a good biostratigraphic marker, e.g., 1) it is a large and distinctive form; 2) it is heavily-calcified and thus particularly resistant to dissolution, and 3) it has a widespread biogeographic distribution. However, one of its main drawbacks is that its abundance is generally very low, and this can result in uneven stratigraphic distribution patterns. As a result, despite the longevity of use of this species in biostratigraphy, the reliability of its biohorizons, especially its Top, are sometimes poorly reproducible.

At Site U1410, the Base of P. gigas lies in the lower part of Chron C20r (Fig. 4), providing an estimated age calibration of 45.29 Ma using the Geological Time Scale 2012 (GTS 2012; Gradstein et al., 2012). This calibration is in fair agreement with that of Agnini et al. (2014), which is ca. 270 kyr older. Though these estimates are relatively close, two main arguments may explain this discrepancy and help to minimize the observed differences in future studies. The first is related to the presence of transitional morphotypes between P. giganteus and P. gigas. Since, at present, there is

no commonly accepted taxonomy for $P$. gigas, previous studies may have adopted a broader or stricter concept of this taxon leading to diachronous results that reflect the different stratigraphic ranges of the two species, rather than representing a real diachroneity. If specimens of $P$. giganteus have been ascribed to $P$. gigas, this would result in an older age estimation for the base of the Zone CNE10 because the first appearance of $P$. giganteus predates that of $P$. gigas. The second argument is related to the depositional setting and the methodology used to calibrate biohorizons. In order to provide age estimates of biohorizons we use magnetostratigraphic data, and in particular the ages of the base and top of the chron where the biohorizon lies, with the important assumption that sediment accumulation rates throughout the chron remain constant. In this particular case, Chron C20r has a long duration (c. $2.3 \mathrm{Myr}$ ), so this assumption could not be easily verified, especially considering that this section is characterized by alternations of clay and carbonate-rich sediments, reflecting variable terrigenous input in a drift sedimentation regime. If sedimentation rate is not constant, then this may affect the age calibration. For this reason, the availability of highly-resolved datasets, ideally astronomically rather than magnetostratigraphically tuned, could provide more reliable age estimations. 
At Ocean Drilling Program (ODP) Site 1051 (North Atlantic Ocean), the Top of $P$. gigas has an age of 43.6 Ma (age recalibrated to GTS 2012; Agnini et al., 2014) and this is slightly younger with respect to our result of $43.82 \mathrm{Ma}$ at $175.21 \mathrm{crmcd}$. However, an isolated specimen was also found at 43.65 Ma (170.74 crmcd) (Fig. 4). The combined effect of several factors (e.g., local abundance, sample preparation and study area) may account for the differences observed between our data and that from Site 1051, with the remarkable scarcity of this taxon observed at Site U1410 constituting the most likely explanation. The reliability of the Top of $P$. gigas is therefore questionable because the abundance pattern of this species is not easily reproducible in its upper range, though variable accumulation rates at IODP Site U1410 could also have contributed to the differences between these calibrations.

Although our data suggest that the Top of $P$. gigas is difficult to be determined precisely, due to the sporadic and rare occurrences in its upper range, there are very few other alternative biohorizons in this time interval. The use of other species within this group, such as $P$. mutatus, may provide useful secondary biostratigraphic information in support of the primary marker species $P$. gigas.

To summarize, the use of a morphometric approach has provided more objective criteria with which to define and identify $P$. gigas. This should improve taxonomic consistency and subsequent biostratigraphic and biochronologic results. Inconsistences introduced by depositional settings however can only be minimized by providing new astrocyclostratigraphic-based data, which are currently not available.

\subsection{The middle Eocene coccolithacean evolutionary lineage in a global context}

Biotic and abiotic factors may all influence the evolution and composition of calcareous nannofossil communities and some indication of which factors are dominant in these roles may be indicated by paleontological and geochemical proxies. Among the environmental factors that affect evolution and diversity of calcareous nannoplankton, those of nutrient availability and temperature are considered the most influential. Here we compare calcareous nannofossil and stable isotope data from Site U1410 in order to examine the relative timings of environmental changes and evolution within the Pletolithus lineage (Fig. 12).

At Site U1410, the stable isotope record shows that Pletolithus appeared during a negative shift of $c$. $0.5 \%$. in the bulk $\delta^{13} \mathrm{C}$ record that is also associated with relative lower $\delta^{18} \mathrm{O}$ values, if compared with the overall $\delta^{18} \mathrm{O}$ trend observed between $276.48 \mathrm{crmcd}$ and $257.57 \mathrm{crmcd}$ (Fig. 12). The successive evolution of Pletolithus taxa through the Lutetian occurred against a backdrop of relative stability with a gradual trend towards cooler conditions. Viewed in the broader context, the stable 
isotope record observed in the lower part of Chron C21n, can be interpreted as a transient warming interval that reversed the cooling trend following the EECO.

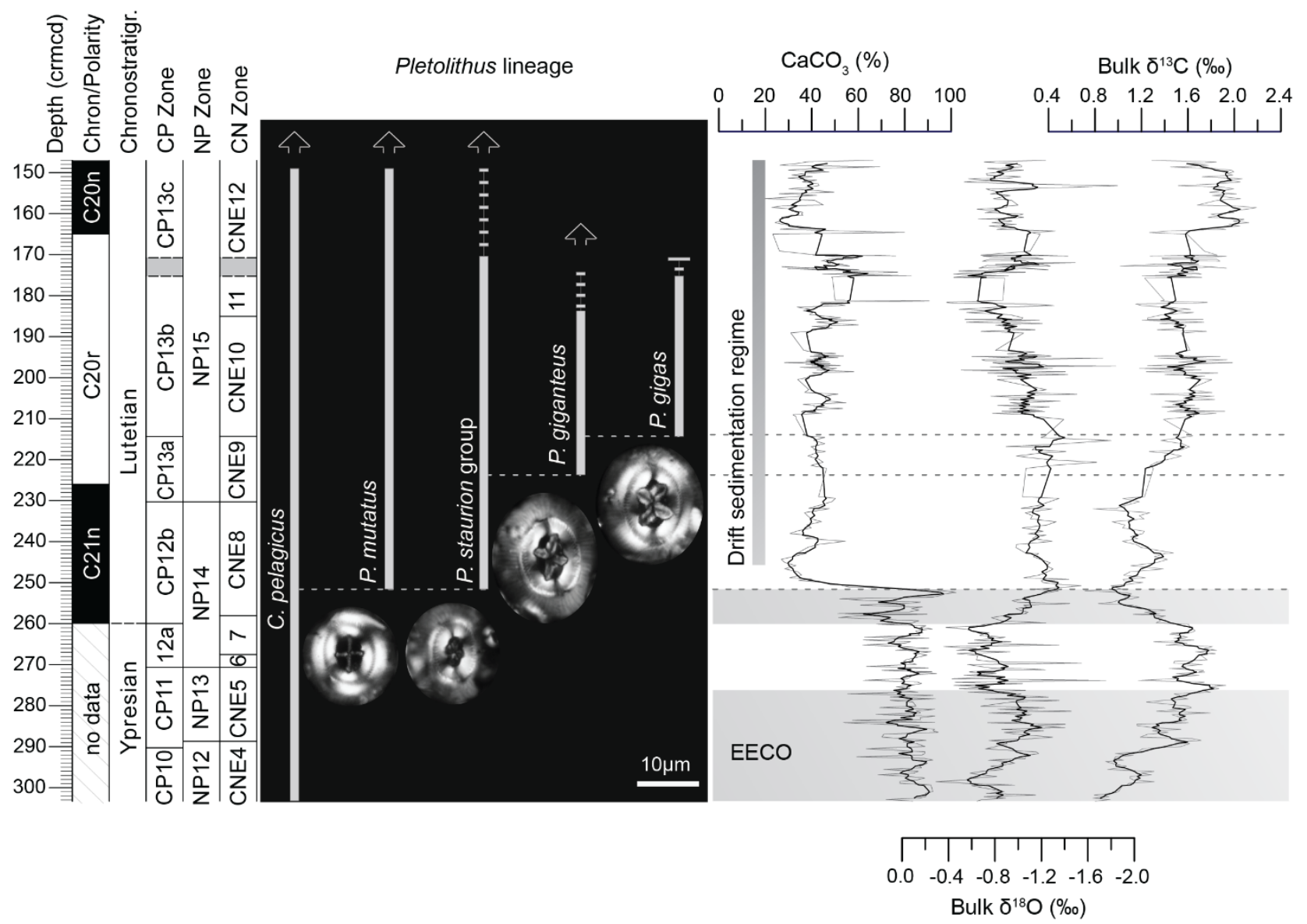

Figure 12: Range chart of species belonging to Pletolithus plotted against depth (crmcd) and records of bulk carbonate $\delta^{13} \mathrm{C}, \delta^{18} \mathrm{O}$ and $\mathrm{CaCO}_{3}$ content from Site U1410 (Cappelli et al., submitted). Magnetostratigraphy and calcareous nannofossil biostratigraphy are also shown (CP Zone, Okada and Bukry, 1980; NP Zone, Martini, 1970; CN Zone, Agnini et al., 2014). Gray bands highlight the EECO warm interval and a distinctive transient negative excursion in $\delta^{13} \mathrm{C}$ record that coincides with the first occurrence of Pletolithus.

The $\mathrm{CaCO}_{3}(\%)$ record shows that the appearance level of Pletolithus is coincident with an interval of instability that slightly precedes the onset of drift sedimentation, likely reflecting a significant change in deep water circulation at this location (Boyle et al., 2017). This new deep water current system may have had a local impact on calcareous nannofossil populations since rates of subsurface and deep-water formation influence the rate of nutrient supply to surface waters. An increase in surface water nutrients is supported by the dominance of reticulofenestrids in the assemblages throughout the Lutetian at Site U1410, a group that is generally interpreted as a meso-eutrophictemperate taxon (Schneider et al., 2011; Shamrock and Watkins, 2012; Fioroni et al., 2015; Villa et al., 2008, 2014). 
The palaeoecological preferences of Pletolithus are as yet poorly constrained, though previous authors have suggested a preference for cooler/meso-eutrophic waters (e.g., Wei and Wise, 1990; Aubry, 1992; Firth and Wise, 1992). However, the large size of these taxa, the fact that they consistently represent a minor component of assemblages in different paleoenvironmental settings and the coincidence of their evolution with a relatively stable environmental conditions are all suggestive of K-mode life strategy, characterized by lower reproductive potential and lower rate of maturation (Mac Arthur and Wilson, 1967). K-mode strategists are in fact better adapted to highlystable, typically warm and oligotrophic environments where organisms compete by specialization and habitat partioning (Hallock, 1987; Hallock et al., 1991; Premoli Silva and Sliter, 1999). This interpretation is supported by the fact that $P$. gigas did not migrate to southern high latitudes (Aubry, 1992), where assemblages are typically dominated by taxa such as Chiasmolithus and Reticulofenestra, which favour cooler and more eutrophic conditions.

The analysis of evolutionary trends during the middle Eocene is particularly interesting because during this time interval calcareous nannofossils reached their maximum diversity (Bown, 2005a), with mesotrophic and oligotrophic assemblages adjacent to one another (ecotonal community, Hallock et al., 1991, Aubry, 1992). We suggest that, as these assemblages were dominated by the opportunistic Reticulofenestra the onset of relatively stable environmental conditions created new niches that were occupied by short-ranging specialized taxa, such as Pletolithus, which disappeared as the transition towards cooler conditions proceeded once more. A more complete understanding of the palaeoecology of this group requires the study of a broader spectrum of depositional settings and conditions.

\section{Conclusion}

The sedimentary succession recovered at Site U1410 has allowed us to document the emergence of a new lineage of large coccolithaceans. We have documented a series of morphological changes that have enabled us to reconstruct the evolutionary history of the biostratigraphically important species Pletolithus gigas. Based on detailed observations in both LM and SEM we propose a new genus, (Pletolithus), a new species (Pletolithus giganteus) and four new combinations (Pletolithus opdykei, Pletolithus staurion, Pletolithus mutatus and Pletolithus gigas).

Biostratigraphic and biometric data have allowed us to refine the species definition of $P$. gigas, and to distinguish the new species $P$. giganteus, which is characterized by the presence of asymmetric cross-bars in the central-area. The overlap of biometric data between these species suggests a gradual evolutionary transition that includes the progressive rotation of the cross-bars from near-axial in $P$. 
giganteus to the diagonal structure of $P$. gigas. The use of the bar-length ratio allows for an objective and easily applied differentiation of these two species.

We have shown that Pletolithus gigas and P. giganteus are not the ancestral forms in this lineage but that a morphotype ascribable to Coccolithus was the most likely progenitor. This ancestor gave rise to the end-members of the lineage through the early, intermediate taxa, P. opdykei and P. staurion. A Coccolithus-like rim and the presence of robust axial to diagonal cross-bars in the central-area are the diagnostic characters of the new genus Pletolithus. The appearance of these kinds of structures in the central-area is interpreted as an example of iterative evolution since other lineages show exactly the same trends in morphologic evolution, including the Cruciplacolithus-Chiasmolithus plexus that emerged in the early Paleocene.

The evolution of Pletolithus occurred during an interval of increasing diversity of calcareous nannofossils and stable environmental conditions. Pletolithus is believed to include ecologically specialized taxa that might have occupied newly niches formed when a new equilibrium in the environmental system was reached after the EECO.

\section{SYSTEMATIC PALEONTOLOGY}

Order COCCOLITHALES Haeckel, 1894 emend. Young and Bown, 1997 Family COCCOLITHACEAE Poche, 1913 emend. Young and Bown, 1997

\section{Genus Pletolithus nov.}

Type species. Coccolithus gigas Bramlette and Sullivan, 1961

Derivation of name. From latin pletum, meaning filled, and referring to the cross-bars that fill or near fill the central-area, and from greek lithos meaning rock.

Type locality. IODP Exp. 342 Site U1410, Southeast Newfoundland Ridge, northwest Atlantic Ocean. Type level. Lutetian, Subzones CP12b-CP13b or Zones CNE8-CNE12.

Diagnosis. Placoliths with Coccolithus-type shields and tube, and a central-area spanned by welldeveloped axial to diagonal cross-bars.

Remarks. This genus has many features in common with Coccolithus from which it most likely derives. The diagnostic cross-bars are broad or conspicuous and may partially fill the central opening. The cross-bars may be rotated with respect to the main axes of the placolith. The distal shield is wider than the proximal one. The relative width of the central-area is highly variable, ranging from very narrow to very relatively wide. 
Included species. Cruciplacolithus mutatus Perch-Nielsen, 1971, Coccolithus staurion Bramlette and Sullivan, 1961, Coccolithus opdykei Bown and Newsam 2017, Coccolithus gigas Bramlette and Sullivan, 1961.

Pletolithus opdykei (Bown and Newsam, 2017) comb. nov.

Basionym. Coccolithus opdykei. Bown and Newsam, 2017, p.48, pl. 3, figs 2, 3.

Description. Large placoliths $(<12 \mu \mathrm{m})$ with a narrow central-area filled by broad, axial to near-axial cross-bars.

Pletolithus staurion (Bramlette and Sullivan, 1961) comb. nov.

Basionym. Coccolithus staurion. Bramlette and Sullivan, 1961, p. 141, pl. 2, fig 6.

Description. Very large placoliths $(>12 \mu \mathrm{m})$ with a narrow central-area and robust axial cross-bars (Bown and Newsam, 2017).

Differentiation. Distinguished from Pletolithus opdykei by its larger size.

Pletolithus mutatus (Perch-Nielsen, 1971) comb. nov.

Basionym. Cruciplacolithus mutatus. Perch-Nielsen, 1971, p. 23, pl. 16, fig 6.

Synonyms. Coccolithus mutatus (Perch-Nielsen, 1971) Bown, 2005.

Description. Very large placoliths $(>14 \mu \mathrm{m})$ with wide and raised tube cycle and broad central-area that is spanned by delicate cross-bars. The cross-bars may be axial or slightly rotated with respect to the longitudinal axis of the coccolith, and may be straight or slightly curved. The distal shield consists of 50-60 slightly overlapping elements that give rise to low-angle oblique sutures. The outline is normally to broadly elliptical. The tube cycle is raised and consists of 55-65 elements with complex sutures that partially cover the distal shield. The smaller proximal shield consists of 80-100 elements that show a slightly dextral obliquity in proximal view. Thin cross-bars span the central-area. On the distal side the cross-bars consist of 10-25 rectangular interlocking laths, while on the proximal side they consist of 15-25 wedge-shaped elements. The elements on the proximal side are alternatively oriented and form a unique row that slightly extends into the proximal shield. The complex ultrastructure of the central cross is seen in well preserved specimens under light microscope. The tube cycle is highly birefringent under cross-polarized light.

Differentiation. Pletolithus mutatus can be differentiated from species of Coccolithus by the thin axial or slightly rotated cross-bars spanning the central-area and by the raised tube cycle. The central cross of $P$. staurion is also axial but specimens of this species have more robust cross-bars that almost fill the narrower central-area. 
Derivation of name. From latin giganteus, meaning very big, referring to the very large size of this species.

Diagnosis. Very large $(>16 \mu \mathrm{m})$ elliptical placoliths with narrow to broad central-area spanned by robust bars that form an asymmetric diagonal cross.

Description. Very large coccolithacean with a distal shield consisting of 60-70 elements and an elliptical outline. The tube connecting the two shields is broad and consists of flat elements with complex sutures. The smaller proximal shield is composed of elements with dextral obliquity in proximal view. Specimens belonging to this species show high variability in the width of the centralarea, which can occupy from $7 \%$ to $13 \%$ of the total placolith area. A broad, asymmetric diagonal cross spans the central-area. On the distal side, the bars consist of rectangular plates stacked one on another, whose axes are roughly aligned with the long axes of the bars. On the proximal side, the bars are composed of one row of robust wedge-shaped elements (roughly triangular), normally oriented with the axis of the bar. These elements partially interfinger, but do not interfinger along the full length of the wedge. Thickening at the base of the triangular plate is common and it gives rise to a poorly developed depression along the axis of the bar. Under cross-polarized light, thin median extinction lines run along the bars.

Differentation. Pletolithus giganteus can be distinguished from other species of the genus by the intermediate orientation of the broad cross-bars. Pletolithus giganteus can be differentiated from $P$. staurion by its large size and wider central-area. Pletolithus giganteus can be distinguished from $P$. gigas by the diagonally oriented (X-shaped) cross-bars of the latter form. The most diagnostic feature to distinguish consistently between these species is the bar-length ratio. This value is generally $>1.3$ in $P$. giganteus and $<1.3$ in P. gigas. Pletolithus giganteus can be distinguished from P. mutatus by the more robust cross-bars, their different ultrastructure, and the raised tube cycle.

Coccolith length. 16-22 $\mu \mathrm{m}$

Holotype. Figure 6, fig. D

Holotype length. $21 \mu \mathrm{m}$

Paratype. Figure 6, fig. A

Paratype length. $18 \mu \mathrm{m}$

Type locality. IODP Exp. 342 Site U1410, Southeast Newfoundland Ridge, northwest Atlantic Ocean. Type level. Subzone CP13b (Okada and Bukry, 1980) or Zone CNE10 (Agnini et al., 2014), middle Eocene, Sample U1410C-20X-3, $67 \mathrm{~cm}$.

Range. Restricted to upper subzone CP13a-CP13b (Okada and Bukry, 1980) or upper Zone CNE9Zone CNE10 (Agnini et al., 2014). 
Remarks. The Base of Pletolithus giganteus slightly predates the Base of Pletolithus gigas, which is used to mark both the base of subzone CP13b (Okada and Bukry, 1980) and the base of Zone CNE10 (Agnini et al., 2014).

Occurrence. The species first occurs, with low frequency, in the lower part of Chron 20r.

Repository. Holotype and paratype are deposited in the permanent collection of the Museo di Geologia e Paleontologia dell'Università di Padova (MGPD), Padova, Italy (protocol MGP-PD 32095, MPG-PD 32096.).

Pletolithus gigas (Bramlette and Sullivan, 1961) comb. nov.

Basionym. Coccolithus gigas Bramlette and Sullivan, 1961, p.140, pl. 1, fig. 6.

Synonyms. Sullivania gigas (Bramlette and Sullivan, 1961) Varol, 1992.

Chiasmolithus gigas (Bramlette and Sullivan, 1961) Radomski, 1968

Description. Very large, normally elliptical coccolithacean, with a robust diagonal cross (X-shaped) spanning the narrow central-area. The distal shield is composed of 60-70 elements that are radially oriented or may display a slight dextral obliquity in distal view. On the distal side, the broad tube cycle is composed of 40-50 interlocking elements that are gently inclined towards the central-area. The proximal side consists of 55-65 elements with dextral obliquity in proximal view. The robust diagonal cross-bars have complex construction: on the distal side they consist of axially arranged elements while on the proximal side they are composed of one row of wedge-shaped, transverselyoriented elements. The triangular elements of the proximal side point alternatively in opposite directions and interfinger with each other for almost their entire length. A central depression runs along the axis of the bars. Under cross-polarized light, this construction gives rise to two dark extinction lines. Specimens with two straight and sigmoid bars may be observed. In contrast to the original description, specimens with fine "teeth" along the margin have never been observed, and this may have been a preservational artifact.

Differentation. Pletolithus gigas can be differentiated from the others species of Pletolithus by the robust X-shaped structure in the central-area. Pletolithus gigas can be distinguished by P. giganteus by the shape of the central structure, which has a bar-length ratio lower than 1.3. Pletolithus gigas differs from the species belonging to Chiasmolithus by the ultrastructure of the bars and by the flat tube cycle.

\section{Acknowledgements}

This work was supported by University of Padova SID project [prot. BIRD 161002]. The SEM work was supported by the Department of Earth Sciences, University College London. This 
research used samples and data provided by the International Ocean Discovery Program (IODP). ODP is sponsored by the U.S. National Science Foundation (NSF) and participating countries under management of the Joint Oceanographic Institution (JOI) Inc. We are thankful to one anonymous reviewer for the constructive suggestions and to Richard Jordan for his helpful comments.

\section{REFERENCES}

Agnini, C., Fornaciari, E., Raffi, I., Catanzariti, R., Pälike, H., Backman, J., Rio, D., 2014. Biozonation and biochronology of Paleogene calcareous nannofossils from low and middle latitudes. Newsletters on Stratigraphy, 47, 131-181. https://doi.org/10.1127/0078-0421/2014/004

Aubry, M.-P., 1992. Late Paleogene calcareous nannoplankton evolution: a tale of climatic deterioration. In: Prothero, D. R., Berggren, W. A. (Eds.). Eocene-Oligocene Climatic and Biotic Evolution. Princeton University Press, Princeton, pp. 272-309.

Aubry, M.-P., 1998. Early Paleogene calcareous nannoplankton evolution: a tale of climatic amelioration. In: Aubry, M. P., Lucas, S.G., Berggren, W.A. (Eds.) Late Paleocene-early Eocene Biotic and Climatic Events in the Marine and Terrestrial Records. Columbia University Press, New York, pp. 158-201.

Black, M., 1964. Cretaceous and Tertiary coccoliths from Atlantic seamounts. Palaeontology, 7, 306316.

Bornemann, A., D'haenens, S., Norris, R. D., Speijer, R. P., 2016. The demise of the early Eocene greenhouse - Decoupled deep and surface water cooling in the eastern North Atlantic. Global and Planetary Change, 145, 130-140. https://doi.org/10.1016/j.gloplacha.2016.08.010

Boulila, S., Vahlenkamp, M., De Vleeschouwer, D., Laskar, J., Yamamoto, Y., Pälike, H., Kirtland Turner, S., Sexton, P. F., Westerhold, T., Röhl, U., 2018. Towards a robust and consistent middle Eocene astronomical timescale. Earth and Planetary Science Letters, 486, 94-107. https://doi.org/10.1016/j.eps1.2018.01.00

Boyle, P. R., Romans, B. W., Tucholke, B. E., Norris, R. D., Swift, S. A., Sexton, P. F., 2017. Cenozoic North Atlantic deep circulation history recorded in contourite drifts, offshore Newfoundland, Canada. Marine Geology, 385, 185-203. https://doi.org/10.1016/j.margeo.2016.12.01 
Bown, P. R., 2005a. Calcareous nannoplankton evolution: A tale of two oceans. Micropaleontology, 51, 299-308. https://doi.org/10.2113/gsmicropal.51.4.299

Bown, P. R., 2005b. Palaeogene calcareous nannofossils from the Kilwa and Lindi areas of coastal Tanzania (Tanzania Drilling Project 2003-4). Journal of Nannoplankton Research, 27, 21-95.

Bown, P. R., 2010. Calcareous nannofossils from the Paleocene/Eocene Thermal Maximum interval of southern Tanzania (TDP Site 14). Journal of Nannoplankton Research, 31, 11-38.

Bown, P. R., 2016. Paleocene calcareous nannofossils from Tanzania (TDP sites 19, 27 and 38). Journal of Nannoplankton Research, 36, 1-32.

Bown, P. R., Young, J. R., 1998. Techniques. In: Bown, P. R. (Ed). Calcareous Nannofossil Biostratigraphy. British Micropalaeontological Society Series, Chapman and Hall/Kluwer Academic Publishers, London, pp. 18-28.

Bown, P. R., Dunkley Jones, T., 2006. New Palaeogene calcareous nannofossil taxa from coastal Tanzania: Tanzania Drilling Project Sites 11 to 14. Journal of Nannoplankton Research, 28, 17-34.

Bown, P. R., Dunkley Jones, T., 2012. Calcareous nannofossils from the Paleogene equatorial Pacific (IODP Expedition 320 Sites U1331-1334). Journal of Nannoplankton Research, 32, 3-51.

Bown, P. R., Newsam, C., 2017. Calcareous nannofossils from the Eocene North Atlantic Ocean (IODP Expedition 342 Sites U1403-1411). Journal of Nannoplankton Research, 37, 25-60.

Bown, P. R., Lees, J. A., Young, J. R., 2004. Calcareous nannofossil evolution and diversity through time. In: Thierstein, H. R., Young, J. R. (Eds). Coccolithophores: From Molecular Processes to Global Impact. Springer-Verlag, Berlin Heidelberg New York, pp. 481-508.

Bramlette, M. N, Sullivan, F. R., 1961. Coccolithophorids and related nannoplankton of the Early Tertiary in California. Micropaleontology, 7, 129-188.

Clocchiatti, M., Jerkovic, L., 1970. Cruciplacolithus tenuiforatus, nouvelle espèce de coccolithophoridé du Miocène d'Algerie et de Yougoslavie. Cahiers de Micropaleontologie, 2, 1-6.

Coxall, H. K., Huck, C. E., Huber, M., Lear, C. H., Legarda-Lisarri, A., O'regan, M., Silwinska, K. K., Van De Flierdt, T., De Boer, A. M., Zachos, J. C., Backman, J., 2018. Export of nutrient rich Northern Component Water preceded early Oligocene Antarctic glaciation. Nature Geoscience, 11, 190-196. https://doi.org/10.1038/s41561-018-0069-9 
Firth, J. V, Wise Jr, S. W., 1992. A preliminary study of the evolution of Chiasmolithus in the middle Eocene to Oligocene of Sites 647 and 748. In Wise Jr., S. W., Schlich, R., et al., Proceedings of the Ocean Drilling Program, Scientific Results, 120, pp. 493-508.

Fioroni, C., Villa, G., Persico, D., Jovane, L., 2015. Middle Eocene-lower Oligocene calcareous nannofossil biostratigraphy and paleoceanographic implications from Site 711 (equatorial Indian Ocean). Marine Micropaleontology, 118, 50-62. https://doi.org/10.1016/j.marmicro.2015.06.001

Gartner, S., 1969. Two new calcareous nannofossils from the Gulf Coast Eocene. Micropaleontology, $15,31-34$.

Gartner, S., 1970. Phylogenetic lineages in the lower Tertiary coccolith genus Chiasmolithus. Proceedings of the North American Paleontological Convention, Part G., pp. 930-970.

Gallagher, L. T., 1988. A technique for viewing the same nannofossil specimen in light microscope and scanning electron microscope using standard preparation materials. Journal of Micropalaeontology, 7, 53-57. https://doi.org/10.1144/jm.7.1.53

Gradstein, F.M., Ogg, J.G., Schmitz, M.D., Ogg, G.M., 2012. The Geologic Time Scale 2012. Elsevier, Amsterdam.

Hallock, P., 1987. Fluctuations in the trophic resource continuum: a factor in global diversity cycles? Paleoceanography, 2, 457-471. https://doi.org/10.1029/PA002i005p00457

Hallock, P., Premoli Silva, I., Boersma, A., 1991. Similarities between planktonic and larger foraminiferal evolutionary trends through Paleogene paleoceanographic changes. Palaeogeography, Palaeoclimatology, Palaeoecology, 83, 49-64. https://doi.org/10.1016/0031-0182(91)90075-3

Hammer, Ø., Harper, D. A. T., Ryan, P. D., 2001. PAST: Paleontological statistics software package for education and data analysis, Palaeontologia Electronica, 4, 9.

Hay, W. W., Mohler, H. P, Wade, M. E., 1966. Calcareous nannofossil from Nal'chik (northwest Caucasus). Eclogae Geologicae. Helvetiae, 59, 379-399.

Hay, W.W., Mohler, H.P., Roth, P.H., Schmidt, R.R., Boudreaux, J. E., 1967. Calcareous nannoplankton zonation of the Cenozoic of the Gulf Coast and Caribbean-Antillean area, and transoceanic correlation. Transactions of the Gulf Coast Association of Geological Societies, 17, 428480. 
Kamptner, E., 1963. Coccolithineen-Skelettreste aus Tiefseeablagerungen des Pazifischen Ozeans. Annalen des Naturhistorischen Museums in Wien, 66, 139-204.

Martini, E., 1971. Standard Tertiary and Quaternary calcareous nannoplankton zonation. In: Farinacci, A. (Ed.), Proceedings of the $2^{\text {nd }}$ International Conference on Planktonic Microfossil. Tecnoscienza, Roma, pp. 739-785.

Macarthur, R., Wilson, E. O., 1967. The Theory of Island Biogeography. Princeton University Press, 203 pp.

Norris, R. D., Wilson, P. A., Blum, P. and Scientists Exp. 342. 2014. Site U1410. In Norris, R. D., Wilson, P. A., Blum, P. and Exp. 342 Scientists, Proceedings of the Integrated Ocean Drilling Program, 342, College Station, TX (Integrated Ocean Drilling Program). https://doi.org/10.2204/iodp.proc.342.111.2014

Okada, H., Bukry, D., 1980. Supplementary modification and introduction of code numbers to the low-latitude coccolith biostratigraphic zonation (Bukry, 1973; 1975). Marine Micropaleontology, 5, 321-325. https://doi.org/10.1016/0377-8398(80)90016-X

Perch-Nielsen, K., 1971. Elektronenmikroskopische untersuchungen an Coccolithen und verwandten Formen aus dem Eozan von Danemark. Biologiske Skrifter. Kongelige Danske Videnskabernes Selskab, 18, 1-76.

Perch-Nielsen, K., 1985. Cenozoic calcareous nannofossils. In: Bolli, H. M., Saunders, J. B., PerchNielsen, K. (Eds.), Plankton Stratigraphy. Cambridge University Press, Cambridge. pp. 427-554.

Premoli Silva, I., Sliter, W. V., 1999. Cretaceous paleoceanography: Evidence from planktonic foraminiferal evolution. Special Paper of the Geological Society of America, 332, 301-328.

Prins, B., 1979. Notes on nannology-1. Clausicoccus, a new genus of fossil Coccolithophorids. INA Newsletter, 1, 2-4.

Romein, A.J.T., 1979. Lineages in Early Paleogene calcareous nannoplankton. Utrecht Micropaleontological Bulletins, 22, 1-231.

Sáez, A. G., Probert, I., Geisen, M., Quinn, P., Young, J. R, Medlin, L. K., 2003. Pseudo-cryptic speciation in coccolithophores. Proceedings of the National Academy of Sciences of the United States of America, 100, 7163-7168. https://doi.org/10.1073/pnas. 1132069100 
Schneider, L. J., Bralower, T. J., Kump, L. R., 2011. Response of nannoplankton to early Eocene ocean destratification. Palaeogeography, Palaeoclimatology, Palaeoecology, 310, 152-162. https://doi.org/10.1016/j.palaeo.2011.06.018

Shamrock, J. L., Watkins, D. K., 2009. Evolution of the Cretaceous calcareous nannofossil genus Eiffellithus and its biostratigraphic significance. Cretaceous Research, 30, 1083-1102. https://doi.org/10.1016/j.cretres.2009.03.009

Shamrock, J. L., Watkins, D. K., 2012. Eocene calcareous nannofossil biostratigraphy and community structure from Exmouth Plateau, Eastern Indian Ocean (ODP Site 762). Stratigraphy, 9, 1-54.

Schwarz, E. H. L., 1894. Coccoliths. Annals and Magazine of Natural History, 14, 341-346.

Van Heck, S. E., Prins, B., 1987. A refined nannoplankton zonation for the Danian of the Central North Sea. Abhandlungen der Geologischen Bundesanstalt, 39, 285-303.

Varol, O., 1992. Sullivania a new genus of Palaeogene coccoliths. Journal of Micropalaeontology, 11, 141-149. https://doi.org/10.1144/jm.11.2.14

Villa, G., Fioroni, C., Pea, L., Bohaty, S. M., Persico, D., 2008. Middle Eocene-late Oligocene climate variability: Calcareous nannofossil response at Kerguelen Plateau, Site 748. Marine Micropaleontology, 69, 173-192. https://doi.org/10.1016/j.marmicro.2008.07.00

Villa, G., Fioroni, C., Persico, D., Roberts, A. P., Florindo, F., 2014. Middle Eocene to Late Oligocene Antarctic glaciation/deglaciation and Southern Ocean productivity. Paleoceanography, 29, 223-237. https://doi.org/10.1002/2013PA002518

Watkins, D. K., Bergen, J. A., 2003. Late Albian adaptive radiation in the calcareous nannofossil genus Eiffellithus. Micropaleontology, 49, 231-251. https://doi.org/10.2113/49.3.231

Wei, W., Wise Jr, S.W, 1990. Biogeographic gradients of middle Eocene-Oligocene calcareous nannoplankton in the South Atlantic Ocean. Palaeogeography, Palaeoclimatology, Palaeoecology, 79, 29-61. https://doi.org/10.1016/0031-0182(90)90104-F

Yamamoto, Y., Fukami, H., Taniguchi, W, Lippert, P.C., 2018. Data report: updated magnetostratigraphy for IODP Sites U1403, U1408, U1409, U1410. In Norris, R.D., Wilson, P.A., Blum, P., and the Expedition 342 Scientists, Proceedings of the Integrated Ocean Drilling Program, 
342, College Station, TX (Integrated Ocean Drilling Program). http://doi.org/10.2204/iodp.proc.342.207.2018

Young, J. R., 1992. The description and analysis of coccolith structure. In: Hamrsmid, B., Young, J.R. (Eds.), Nannoplankton Research, I General topics, Mesozoic biostratigraphy. Knihovnicka ZPN, 14a, pp. 35-71.

Young, J. R., Bown, P. R., 1997. Cenozoic calcareous nannoplankton classification. Journal of Nannoplankton Research, 19, 36-47.

Zachos, J. C., Pagani, H., Sloan, L., Thomas, E., Billups, K., 2001. Trends, rhythms, and aberrations in global climate $65 \mathrm{Ma}$ to present. Science, 292, 686-693. https://doi.org/10.1126/science.1059412 Zachos, J. C., Dickens, G. R., Zeebe, R. E., 2008. An early Cenozoic perspective on greenhouse warming and carbon cycle dynamics. Nature, 451, 279-283. https://doi.org/10.1038/nature06588 